Konya Mühendislik Bilimleri Dergisi, c. 9, s. 4, 1088-1108, 2021

Konya Journal of Engineering Sciences, v. 9, n. 4, 1088-1108, 2021

ISSN: 2667-8055 (Elektronik)

DOI: $10.36306 /$ konjes.925801

\title{
KOCAELİ-GEBZE TAVŞANLI BÖLGESİ KİREÇTAŞLARININ BETON AGREGASI OLARAK KULLANILABILIIRLIĞİNIN ARAŞTIRILMASI
}

\author{
${ }^{1}$ Hüseyin AKYILDIRIM ${ }^{(\mathbb{D})},{ }^{2}$ Ahmet KARAKAŞ \\ ${ }^{1}$ Kocaeli Üniversitesi, Fen Bilimleri Enstitüsü, Jeoloji Mühendisliği Anabilim Dal, Kocaeli, TÜRKIYYE \\ ${ }^{2}$ Kocaeli Üniversitesi, Mühendislik Fakültesi, Jeoloji Mühendisliği Bölümü, Kocaeli, TÜRKIYYE \\ 1akyildirimh@gmail.com, 2akarakas@kocaeli.edu.tr
}

(Geliş/Received: 26.04.2021; Kabul/Accepted in Revised Form: 24.11.2021)

ÖZ: Bu çalışmada, Kocaeli - Gebze Tavşanlı bölgesinde geniş yayılım gösteren Triyas yaşlı kireçtaşlarının beton agregası olarak kullanılabilirlikleri araştırılmıştır. Kırmataş ocağının mostrasından alınan kaya numunelerinin jeolojik ve petrografik özelliklerinin yanı sıra kırma eleme tesislerinde kaya numuneleri boyut küçültme ve sınıflandırma işlemine tabii tutulması ile elde edilen agrega numunelerinin kimyasal, fiziksel ve mekanik özellikleri standart agrega deneyleri yapılarak incelenmiştir. Ayrıca agrega özelliklerinin betona etkisini araştırmak amacıyla beton deneyleri yapılarak normal dayanımlı betonda agrega olarak kullanılabilirlikleri araştırılmıştır. İncelenen kireçtaşı agregalarının petrografik özelliklerinin yanı sıra agrega özellikleri ve beton deneyleri sonucunun standartlarda belirtilen kabul edilebilir limitler aralığında bulunması nedeniyle beton agregası olarak kullanılmaları uygundur.

Anahtar Kelimeler: Kireçtaşı, Agrega Özellikleri, Beton Agregası

\section{Limestones of Kocaeli-Gebze Tavşanlı Region Investigation of Usage as Concrete Aggregate}

\begin{abstract}
In this study, the usability of Triassic aged limestones, which are widely distributed in Kocaeli - Gebze Tavşanlı region, as concrete aggregate was investigated. In addition to the geological and petrographic properties of the rock samples taken from the outcrop of the crushed stone quarry, the chemical, physical and mechanical properties of the aggregate samples obtained by subjecting the rock samples to size reduction and classification in crushing and screening plants were investigated by performing standard aggregate tests. In addition, in order to investigate the effect of aggregate properties on concrete, concrete experiments were carried out and their use as aggregate in normal strength concrete was investigated. In addition to the petrographic properties of the examined limestone aggregates, it is appropriate to use them as concrete aggregate because the aggregate properties and concrete test results are within the acceptable limits specified in the standards.
\end{abstract}

Key Words: Limestone, Aggregate Properties, Concrete Aggregate

\section{GİRIŞ̧ (INTRODUCTION)}

Beton üretiminde, kırmataş ocaklarında kireçtaşlarından üretilen agregalar yoğun olarak kullanılmaktadır. Özellikle yapılaşmanın hızla arttığı Kocaeli ve İstanbul'da beton ve dolayısıyla agrega ihtiyacı oldukça fazladır. Artan şehirleşme hızı ile birlikte daha yüksek veya daha geniş kapasiteli yapılara yönelim olmaktadır. Yapıların güvenliği için beton kalitesi çok önemlidir. Agregalar, beton hacminin yaklaşık \%75'ini oluşturduğundan kaliteli beton üretimi için önemli bir bileşendir (Erdoğan, 2003). 
Gelişen teknoloji ile birlikte beton üretiminde agrega seçiminin önemi artmaktadır. Çünkü su/çimento oranını belirleyen agreganın kalitesi olduğu için iyi agregadan iyi bir beton üretimi yapılabilmektedir.

Kireçtaşı, bazalt ve kumtaşı gibi hammadde ocaklarından delme-patlatma yöntemiyle gevşetilen kayaçların kırma eleme tesislerinde boyut küçültme ve sınıflandırma işlemine tabii tutulması neticesinde agrega elde edilir. Ülkemizde agrega üretimi doğal kum-çakıl ocaklarından yani akarsu yataklarından, alüvyon deltalarından ve doğal taş ocaklarından yapılmaktadır. Günümüzde ise agrega üretimi olarak taş ocakları faaliyetleri her geçen gün artmaktadır. Agregalar; betonun hammaddesini oluşturan kum, çakıl ve kırmataş karışımından oluşan organik olmayan malzemelerdir. Su, çimento ve kimyasal katkı ile uygun oranda karıştırıldı̆̆ında beton elde edilmektedir. Agregalar beton malzemesi, dolgu ve 1slah malzemesi, yol inşaatlarında asfalt ve temel malzemesi olarak yaygın kullanılmaktadır.

Farklı agrega türleri üzerinde araştırmalar yapan Gutierrez ve Canovas (1996), Taşdemir (1998) ve Poitevin (1999); betonun kıvamını etkileyen temel agrega özelliğinin su emme, diğer özelliklerin ise; tane şekli, tane boyu dağılımı, en büyük tane boyutu olduğunu vurgulamıştır. Poitevin (1999) ayrıca kireçtaşlarının betonda kullanılabilirliklerinin en önemli ölçütlerinden birinin Los Angeles parçalanma oranı olduğunu belirtmiştir (Güler ve diğ., 2010). Al-Jassar ve Hawkins (1991); kireçtaşlarının kimyasal ve petrografik özelliklerini araştırarak kireçtaşlarının litolojilerinin basınç ve alkali karbonat reaksiyonuna etkisini incelemişlerdir. Williams ve Mc Namara (1992); farklı özelliklere sahip kireçtaşları üzerinde yapılan çalışmalar ile kireçtaşlarının bileşim farklılığının dayanım özelliklerini etkilediğini belirtmişlerdir. Uribe-Afif (1994); kireçtaşlarının beton agregası özelliğini araştırdığı çalışmada kireçtaşlarında meydana gelen ayrışmaların agrega kalitesini etkilediğini ve ayrışma sonucu oluşan ince agreganın betonun dayanımını düşürdüğünü ifade etmiştir (Arsoy ve dĭ̆., 2018).

Zarif ve diğ. (2003); İstanbul'daki kireçtaşlarının agrega kalitesi yönünden değerlendirilmesini yaptıkları çalışmalarında kireçtaşlarının bileşim ve dokusal olarak farklılıkları üzerinde durmuşlar ve bu değişik özellikteki kireçtaşlarının agrega olarak kullanılabilirliklerini araştırmışlardır. Keskin (2011); İstanbul'un Avrupa yakasındaki, Ayazağa bölgesinde yer alan Cendere vadisi kayaçları beton agregası olarak araştırmıştır. Çalışmada beton agregalarının uygunluğu değerlendirirken agregaların fiziksel, kimyasal, mineralojik-petrografik özellikleri ve alkali agrega reaksiyon riski özelliklerinin bir arada değerlendirilmesi gerektiğinin önemi vurgulanmıştır. Gürsel ve Erenson (2017); 24 farklı kayaç türü ve petrografik özelliklerinin yüksek dayanımlı beton üretiminde etkisini araştırdıkları çalışmada, agregaların kayaç petrografik özelliklerinin agrega kalitesi hakkında ön bilgi verse de yüksek dayanımlı betonlarda kullanılacak agregalar için tek başına agrega kalitesini belirleme de yeterli olmadığını vurgulamışlardır.

Günümüzde, Kocaeli ve İstanbul'da kireçtaşlarından üretilen agregalar yoğun bir şekilde beton yapımında kullanılmaktadır. Kireçtaşları, yaygın bulunması ve çimento ile aderansının diğer kayaçlara göre daha iyi olması nedeni ile farklı bir öneme sahiptir. Bu çalışmada Kocaeli ve İstanbul'un agrega ihtiyacını gideren Kocaeli - Gebze İlçesi, Tavşanlı Bölgesi'ndeki kireçtaşı ocağında üretilen agregaların beton üretimi için uygunluğu araştırılmıştır. Çalışma alanından alınan kayaç numunelerinin mineralojik ve petrografik özellikleri incelenerek detaylı kayaç analizi yapılmış bu özelliklerle birlikte standart agrega ve beton deneyleri ile kireçtaşlarının beton agregası olabilirlikleri, silis mineral içeren kireçtaşı agregalarına ise hızlandırılmış harç çubuğu yöntemi uygulanarak alkali silika reaksiyon riskinin belirlenmesi ile betonda kullanımının uygunluğu araştırılmıştır.

\section{İNCELEME ALANI (INVESTIGATION AREA)}

İnceleme alanı içerisinde yer alan özel bir maden firması tarafından işletilmekte olan kireçtaşı ocakları Kocaeli - Gebze İlçesi, Tavşanlı Köyü Suçıkan Deresi mevkiinde bulunmaktadır. Çalışma alanı İstanbul İzmit E5 Devlet Karayolu'nun kuzeyinde, Kocaeli ili Gebze İlçesi'nin kuzeydoğusunda olup İstanbul'a 60 km mesafe uzaklıktadır (Şekil 1).

İncelenen taş ocağı, kireçtaşlarının yayılım gösterdiği Taşkaldıran Alçağı ile Suçıktı Deresi'nin batı ve doğu yamaçlarında yer almaktadır. Bölge, Jeolojik süreçlerde aşınmaya maruz kaldığından engebeli bir morfolojiye sahiptir. 


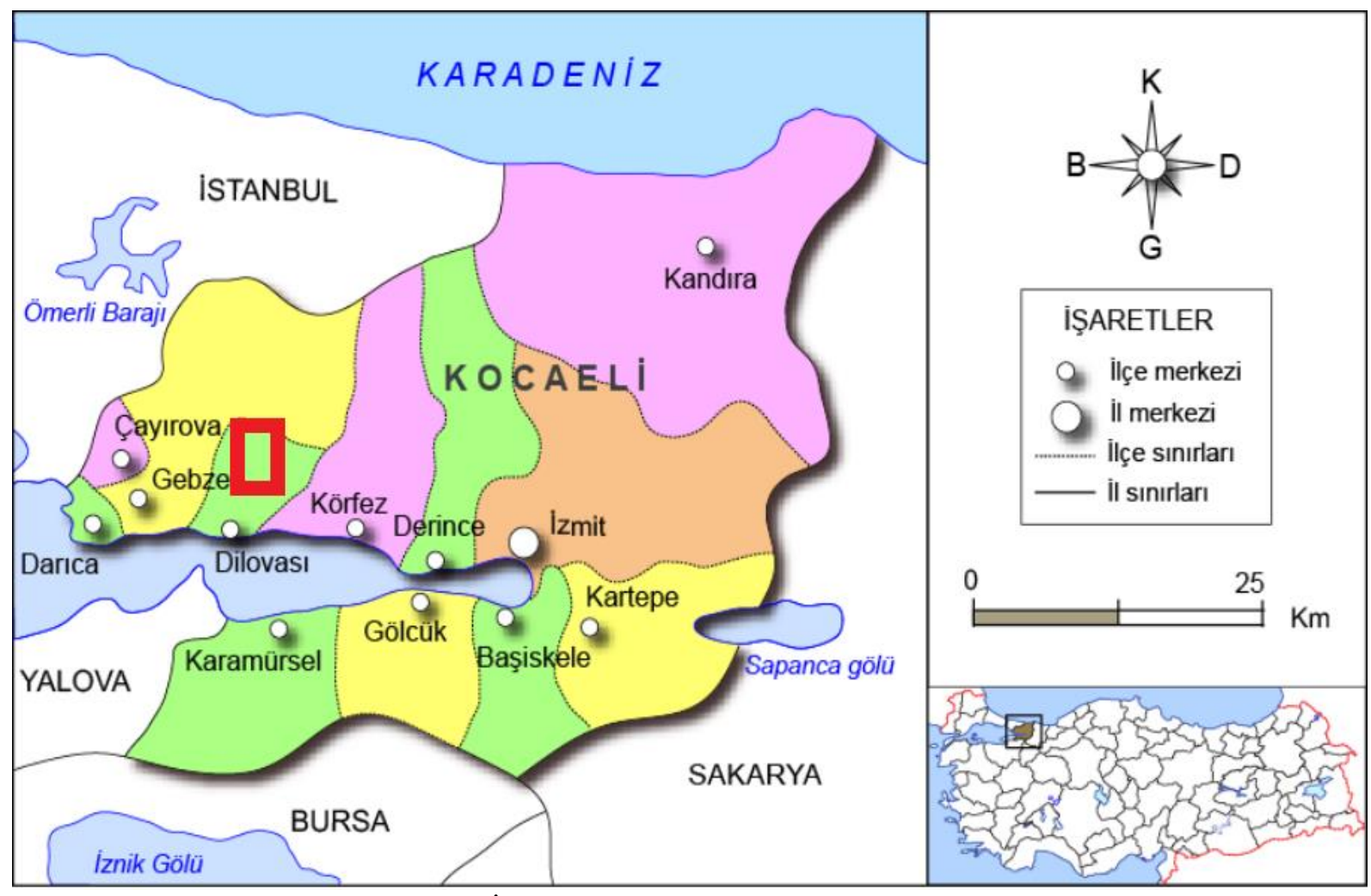

Şekil 1. İnceleme alanının yer bulduru haritası

Figure 1. Location map of the study area

\section{İNCELEME ALANININ JEOLOJISİ (GEOLOGY OF THE INVESTIGATION AREA)}

İncelenen agrega ocağında ağırlıklı olarak Hereke Formasyonuna ait kireçtaşları seviyelerinden kırmataş agrega üretilmektedir. Kireçtaşları yoğun, masif görünümlü, ince - orta taneli ve gri, mavimsi gri renklidir (Şekil 2). Karstlaşma nedeniyle tabaka ve çatlaklarda erime boşlukları gelişmiş olup bu boşlukları birimde aralıklarla yer alan kırmızı renkli kil ve silt malzemeleri doldurmuştur (Halili ve Gözübol, 1999). Bölgede; Paleozoyik, Mesozoyik ve Senozoyik yaşlı sedimanter formasyon ve birimler yer almaktadır. Triyas yaşlı birimler Karbonifer serileri üzerine transgresif olarak açılı bir uyumsuzlukla gelirler. Hereke dolayındaki Triyas yaşlı birimler; Kapaklı, Erikli, Hereke ve Tepecik formasyonları olarak adlandırılmıştır. Kretase'yi ise Kutluca ve Şemsettin formasyonları temsil etmektedir (Şekil 3).

Karbonifer yaşlı seriler üzerine açılı bir uyumsuzlukla gelen Alt Triyas yaşlı Kapaklı formasyonu kötü boylanmalı genellikle iri çakıllar içeren taban çakıltaşı ile başlar. Üstte doğru taneleri incelen kötü boylanmalı, az yuvarlaklaşmış, ince-kalın çapraz tabakalı karasal akarsu çökellerinden oluşan kumtaşları içerir. Kapaklı formasyonunun üzerine uyumsuz olarak gelen Alt Triyas yaşlı Erikli formasyonu, tabanda sarı kumtaşı olup üst kısımlarda kumlu kireçtaşına geçiş göstermektedir. Beyazımsı, sarı olan kumlu kireçtaşı taneli dokuya sahiptir. Üst kesimlerine doğru çok ince taneli olup alacalı pembe bir renk kazanmaktadır. Erikli formasyonu üzerine uyumlu olarak gelen Alt-Orta Triyas yaşlı Hereke formasyonu beyazımsı-koyu, gri ve mavimsi gri kireçtaşlarından oluşur. Çok ince, ince-orta ve kalın tabakalardan oluşan birim dolomitik seviyeleri de içinde bulundurmaktadır. Bölgenin maruz kaldığı tektonizma sebebiyle Hereke formasyonu kıvrılmış, kırılmış ve faylanmıştır. Bu hareketler sonucu doğan gerilmeler kireçtaşında bir takım fay ve kırıklara neden olmuştur. Faylanmalar ile oluşan ezik zonlar boyunca ayrışma olayları ileri derecede etkili olmuştur. Derinlere inen topraklaşma ve karstlaşma olayları ile de formasyon yerel olarak zayıf, dayanıksız, ezik ve bozuk bir malzeme özelliği kazanmıştır (Eren ve diğ., 1996). Hereke Formasyonunun üzerine uyumsuzlukla gelen Üst Triyas yaşlı Tepecik formasyonu 
beyazımsı krem şeyllerden oluşur. Tabanda boz olan ve giderek kırmızımsı renk alan ince-orta tabakalı kireçtaşı ile başlayıp üste doğru boz- krem şeyl-kireçtaşı-kumtaşı ardalanması şeklinde devam etmektedir.

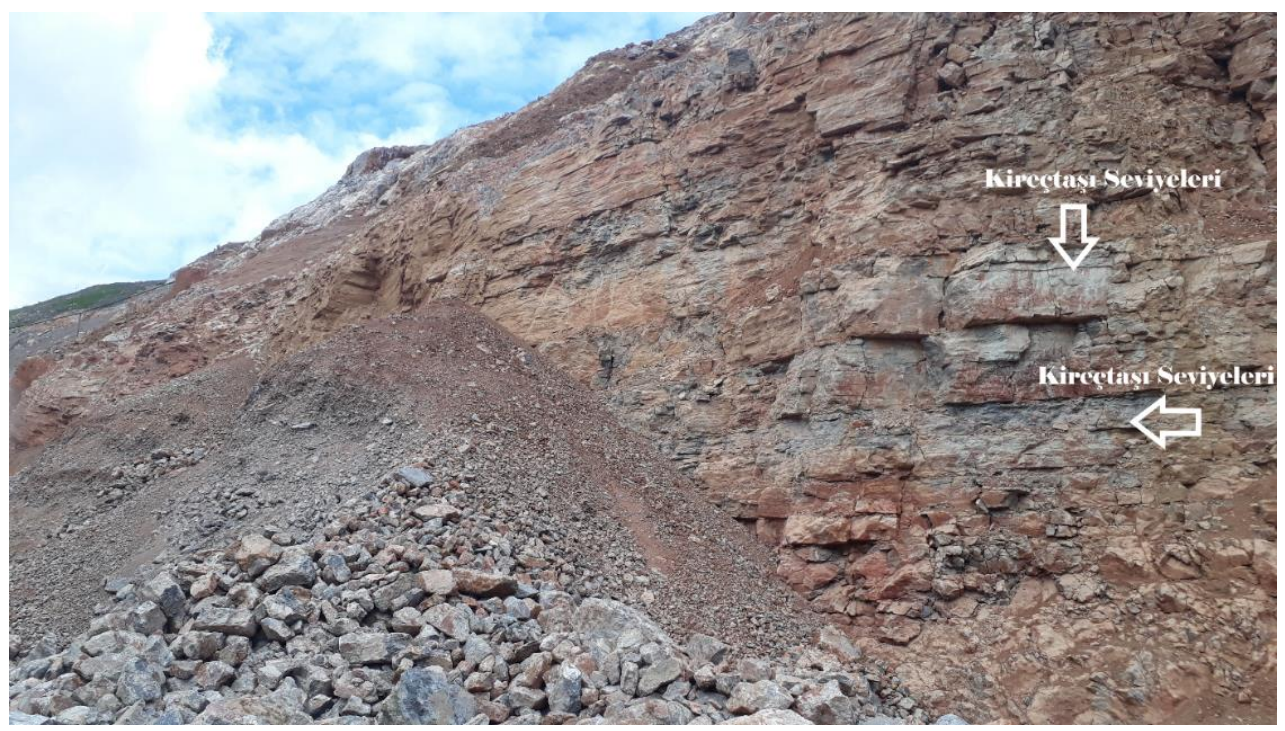

Şekil 2. Hereke Formasyonun kireçtaşı seviyeleri

Figure 2. Limestone levels of the Hereke Formation

Triyas serileri, Kretase birimleri üzerine bindirmiş olarak görülürler. Kretase'yi tabanda bol Rudistli ve Bentik foraminiferli kıyı karbonatları olan Kutluca Formasyonu (Eep, 1987) ile aglomera-kumtaşı ve çamurtaşlarından oluşan Şemsettin Formasyonları temsil eder (Eren ve diğ., 1996). İnceleme alanında en üst seviyelerde çakıl ve kumdan oluşan Çukurçeşme formasyonu (Sayar, 1976) ile akarsu yataklarında çakıl, kum, kil ve silt gibi malzemelerinden oluşan alüvyon görülmektedir.

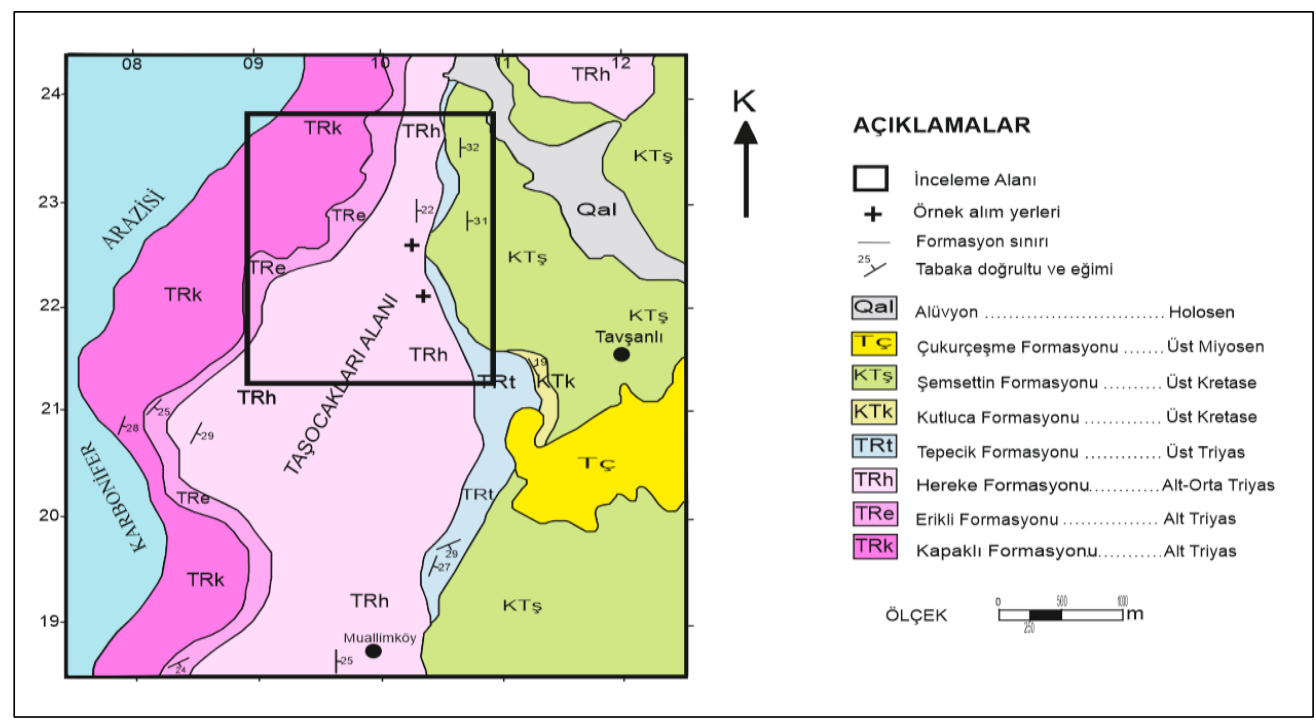

Şekil 3. İnceleme alanının jeoloji haritası (Eren ve diğ., 1996)

Figure 3. Geological map of the study area 


\section{MALZEME VE YÖNTEM (MATERIAL AND METHOD)}

Çalışmada kullanılan kireçtaşı örnekleri Kocaeli - Gebze İlçesi Tavşanlı Köyü bölgesinde faaliyet gösteren kırmataş ocağından temin edilmiştir (Şekil 4). Alınan kireçtaşları ile agrega üretiminin yapıldığ kırma-eleme tesislerinden standartta belirtilen agrega boyutlarına göre agrega numuneleri alınmıştır.

Deneylerde kullanılan kireçtaşı agregalarının özelliklerini belirlemek amacıyla mineralojik, petrografik ve kimyasal analiz (XRF) yapılmıştır. Mineralojik ve petrografik tanımlamalar amacıyla kırmataş ocaklarında üretilen kireçtaşlarının farklı lokasyonlarından iki adet kayaç-numunesi alınarak makroskobik özellikleri belirlenmiş, el örneklerinden ince kesitler hazırlanarak polarizan mikroskobu ile mikroskobik özellikleri araştırılmıştır. Ayrıca optik mikroskobik analiz yöntemiyle mineralojik bileşimleri tanımlanamayacak nitelikte olan numuneler toz haline getirilerek XRD (X- Işını) yöntemiyle standartlara uygun olarak ayrıntılı mineralojik tanımlamalar yapılmıştır.

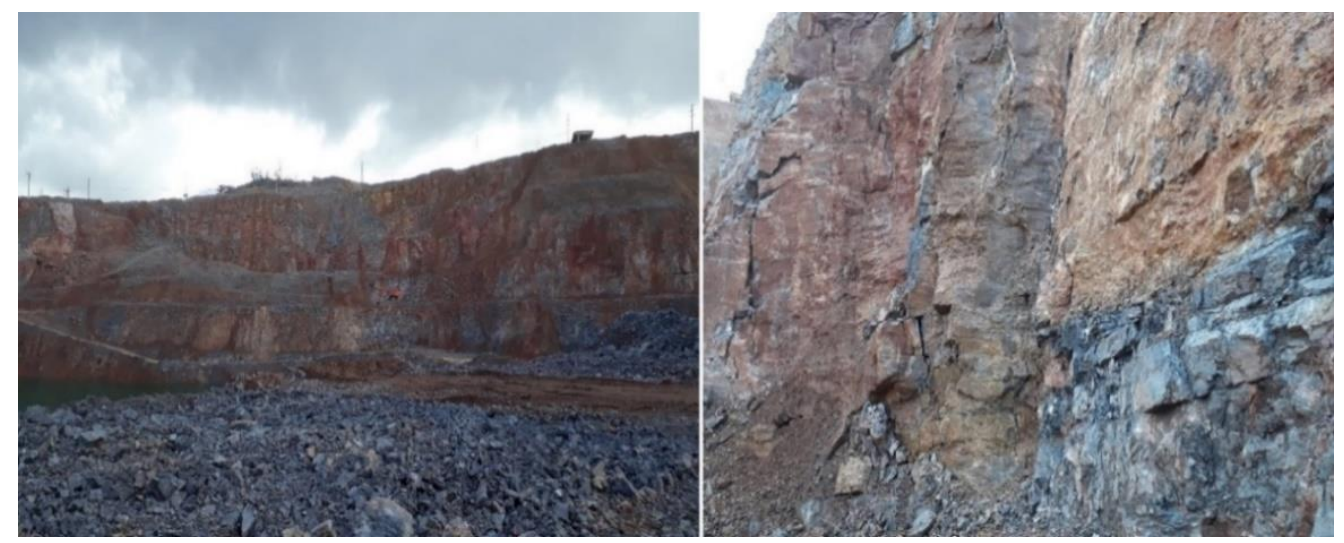

Şekil 4. Gebze kırmataş ocağ1 ve kireçtaşların görünümü

Figure 4. Gebze crushed stone quarry and view of limestones

Gebze kırmataş ocağından alınan agrega numuneleri deneylerde kullanılmak üzere 3 farklı fraksiyonda sınıflara ayrılmıştır (kuru ve yıkanmış $(0-4 \mathrm{~mm})$ ince agrega ve kırmataş $1(4-12 \mathrm{~mm})$ ve kırmataş 2 (12-22 mm) iri agrega). Beton agregası olarak kullanılabilirliği incelenen kireçtaşı agregalarının TS 706 EN 12620 (2003) Standardına uygun olup olmadığını incelemek amacıyla yapılan deney ve analizler Çizelge 1' de verilmiştir.

Çizelge 1. Yapılan deneyler ve ilgili standartlar Table 1. Tests and related standards

\begin{tabular}{|c|c|}
\hline \\
\hline Deneylerin Adı & Deney Standartları \\
\hline $\begin{array}{l}\text { Kimyasal analizler: Asitte çözülen sülfat, } \\
\text { Toplam kükürt, Klorür oranı }\end{array}$ & TS EN 1744-1+A1 (2013) \\
\hline Tane büyüklüğü dağılımı tayini & TS EN 933-1 (2012) \\
\hline Çok ince malzeme muhtevası & TS EN 933-1 (2012) \\
\hline Metilen mavisi deneyi & TS EN 933-9+A1 (2014) \\
\hline Tane yoğunluğu ve su emme oranının tayini & TS EN 1097-6 (2013) \\
\hline Yassillk endeksi & TS EN 933-3 (2012) \\
\hline Los Angeles parçalanma dayanımı & TS EN 1097-2 (2010) \\
\hline Mikro-Deval aşınma dayanımı & TS EN 1097-1 (2011) \\
\hline Alkali-Silika reaktivitesi & ASTM C 1260-14 (2014) \\
\hline Betonun çökme deneyi & TS EN 12350-2 (2019) \\
\hline Betonun birim ağırlığı & TS EN 12350-6 (2019) \\
\hline Betonun serbest basınç dayanımı & TS EN 12390-3 (2019) \\
\hline
\end{tabular}


Beton üretiminde kullanılan kum, çakıl, kırmataş gibi malzemelerin genel adı agregadır. Beton içinde hacimsel olarak \%75 oranında yer işgal eden agrega önemli bir bileşendir. Bu oranın yüksek olması, agregaların hammaddesinin kayaçlardan oluşması ve betonda diğer önemli bileşen olan bağlayıcı malzemesinin kayaçlardan elde edilmesi nedeniyle beton, petrografik açıdan kayaçlara oldukça benzemektedir. Beton tasarımı yaparken agreganın hangi hammadde (kayaç) den elde edildiğinin önemine vurgu yapmak için çalışma alanında yer alan kireçtaşlarının mineralojik ve petrografik özellikleri incelenerek detaylı kayaç analizi yapılmıştır. İncelenen kireçtaşlarının kimyasal analiz ile ana oksit yüzdeleri ve bu yüzdeler kullanarak kireçtaşlarının saflık dereceleri verilmiştir (Çizelge 3). Bölgede bulunan kırmataş üretim tesislerinden elde edilen farklı boyutlardaki kırma kum, yıkanmış kırma kum, kırmataş 1 ve kırmataş 2 olarak tanımlanan agregaların fiziksel, kimyasal ve mekanik özellikleri standart agrega deneyleri ile belirlenmiştir. İncelenen kireçtaşlarından hazırlanan agregaların beton özelliklerine etkilerini araştırmak amacıyla laboratuvarda deneme betonları üretilmiştir. Taze betonda çökme ve birim ağırlık, sertleşmiş beton üzerinde ise 2, 7 ve 28 günlük yaşlar sonrası basınç dayanımı belirlenmiştir. Ayrıca kireçtaşlarının ana oksit yüzdelerine göre; kireçtaşı ve saf olmayan kireçtaşı olarak adlandırılan ve silisli mineral içeren kireçtaşı agregaları ile hızlandırılmış harç çubuğu yöntemi uygulanarak alkali silika reaksiyon riski belirlenmiştir.

\section{BULGULAR (RESULTS)}

Kireçtaşlarının Mineralojik ve Petrografik Özellikleri (Mineralogical and petrographic properties of limestones)

Çalışma alanındaki kırmataş ocaklarında üretilen kireçtaşlarının mineralojik ve petrografik özelliklerini belirlemek için el örneklerinden ince kesitler hazırlanarak polarizan mikroskobu ile incelemeler yapılmıştır. Kireçtaşları; bileşenlerinin yaklaşık yüzde oranları kullanılarak Folk (1962)'e göre "oomikritik kireçtaşı" ve "yarı mikritik-fosilli kireçtaşı" olarak sınıflandırılmıştır. Ayrıca kireçtaşlarının mineralojik ve petrografik özellikleri modal analizi yapılarak Çizelge 2' de sunulmuştur.

Çizelge 2. Hereke Formasyonuna ait kireçtaşının petrografik özellikleri (Folk, 1962) Table 2. Petrographic properties of limestone belonging to the Hereke Formation

\begin{tabular}{|c|c|c|c|c|c|}
\hline $\begin{array}{l}\text { Numune } \\
\text { Kodu }\end{array}$ & Renk & Bileşenler & $\begin{array}{c}\text { Tane } \\
\text { Boyutu }\end{array}$ & Doku & Sinıflama \\
\hline KRÇ-1 & $\begin{array}{l}\text { Açık Gri } \\
\text { N7* }\end{array}$ & $\begin{array}{l}\% \text { 90,0 Kalsit }\left(\mathrm{CaCO}_{3}\right) \\
\% \text { 3,14 Ankerit }\left(\mathrm{Ca}(\mathrm{Fe}, \mathrm{Mg})\left(\mathrm{CO}_{3}\right)_{2}\right) \\
\% \text { 6,66 Nontronit } \\
\left(\left(\mathrm{CaO}{ }_{0.5}, \mathrm{Na}\right)_{0.3} \mathrm{Fe}^{3+}{ }_{2}(\mathrm{Si}, \mathrm{Al})_{4} \mathrm{O}_{10}(\mathrm{OH})_{2} \cdot \mathrm{nH}_{2} \mathrm{O}\right. \\
)\end{array}$ & $\begin{array}{l}\text { İnce- } \\
\text { orta }\end{array}$ & $\begin{array}{l}\text { Kirintılı } \\
\text { doku }\end{array}$ & $\begin{array}{l}\text { Oomikritik } \\
\text { Kireçtaşı }\end{array}$ \\
\hline KRÇ-2 & $\begin{array}{c}\text { Soluk } \\
\text { Mavi 5PB } \\
7 / 2^{*}\end{array}$ & $\begin{array}{l}\% \text { 88,0 Kalsit }\left(\mathrm{CaCO}_{3}\right) \\
\% 12,0 \text { Kuvars }\left(\mathrm{SiO}_{2}\right)\end{array}$ & Orta & $\begin{array}{l}\text { Kirıntilı } \\
\text { doku }\end{array}$ & $\begin{array}{c}\text { Yarı } \\
\text { mikritik- } \\
\text { fosilli } \\
\text { Kireçtaşı }\end{array}$ \\
\hline
\end{tabular}

*Geological Rock-Color Chart (2009)

KRÇ1 numunesi genel olarak kalsitten ibaret oolit ve karbonat çamurlarının mikritik nitelikte bir bağlayıcı malzeme ile bağlandığı görülmektedir (Şekil 5). KRÇ2 numunesi ise çok fazla altere olduğu için karbonat çamuru içerisinde kil mineralleri, küçük kalsit mineralleri, mikro fosil ve kavkıları, kuvars ve opak minerallerinden oluşmaktadır. İncelenen kayaçların ana bileşenleri kalsit, kuvars ve mikro fosil ve kavkılarıdır. Dokusal olarak kırıntılı bir doku görünümündedir. Kalsit taneleri birincil (mikritik kalsit) ve daha iri boyutlu ikincil kalsitler olmak üzere iki türden oluşmaktadır. Kayaçların çoğunlukla karbonatlı minerallerden (kalsit) oluştuğu görülmüştür (Şekil 5). 

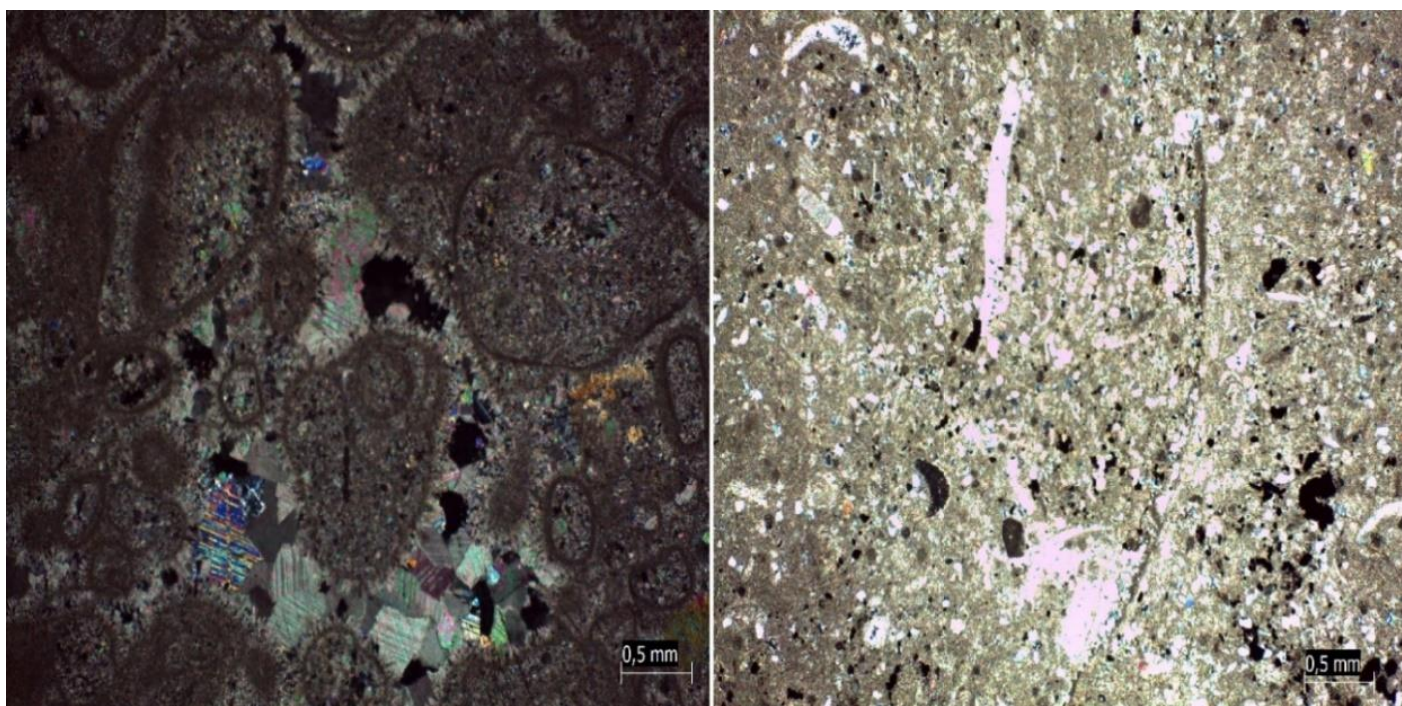

Şekil 5. Kireçtaşlarının ince kesit görünümleri (Çift nikol)

Figure 5. Thin section view of limestones (Pair Nicol)

İncelenen iki kireçtaşı numunesinin XRD analiz sonucu Şekil 6 ve Şekil 7'de verilmiştir. XRD analizi sonucunda kireçtaşlarının büyük oranda kalsit ve kuvars minerallerinden meydana geldiği belirlenmiştir. Bunlara ek olarak dolomite benzer koşullarda oluşan ankerit minerali ve simektit grubu kil minerali olan nontronit mineralleri tespit edilmiştir.

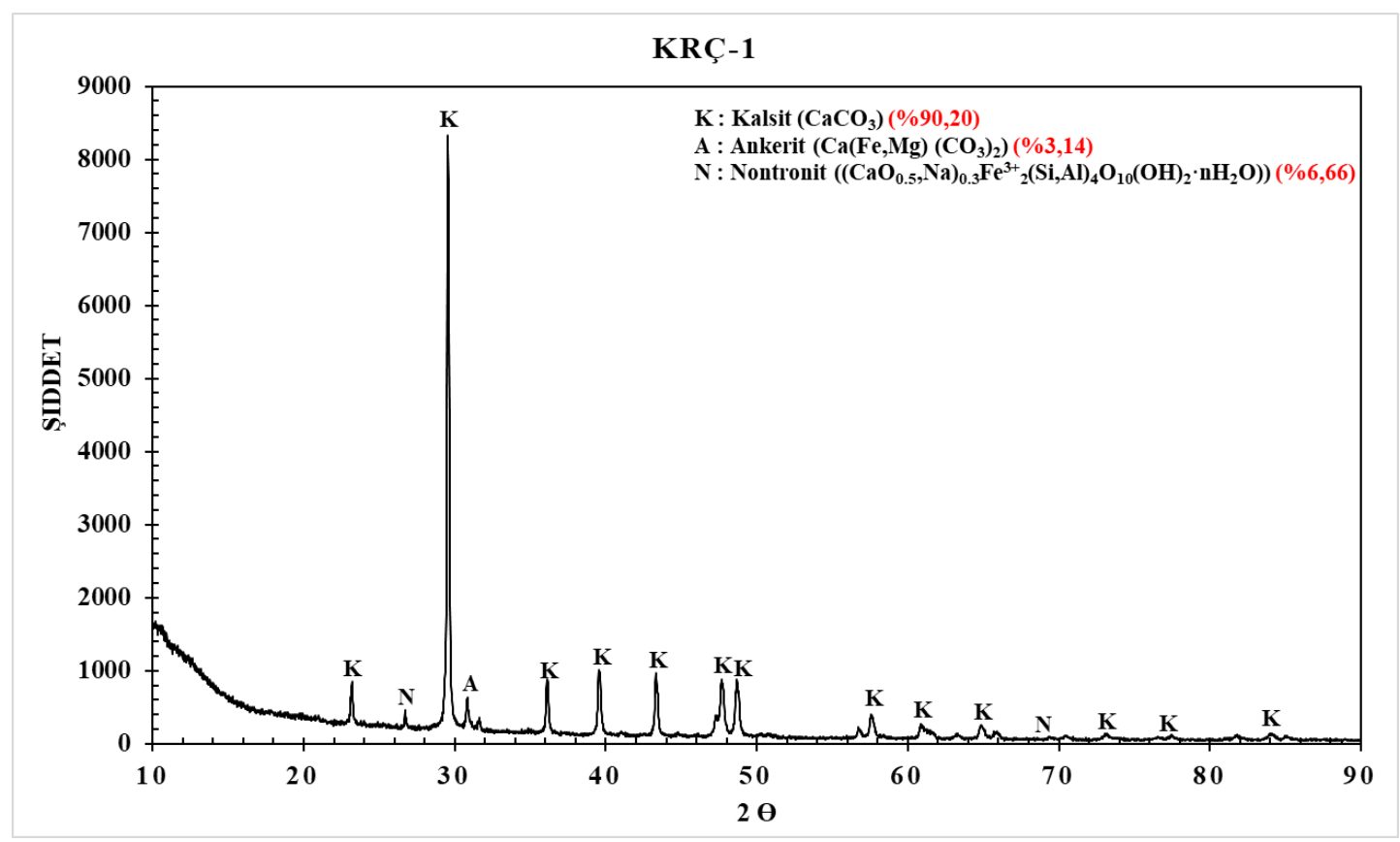

Şekil 6. KRÇ-1 numunesine ait XRD grafiği ve içeriği oluşturan minerallerin \% dağılımı

Figure 6. The XRD graph of the KRÇ-1 sample and the \% distribution of the minerals that make up the content 


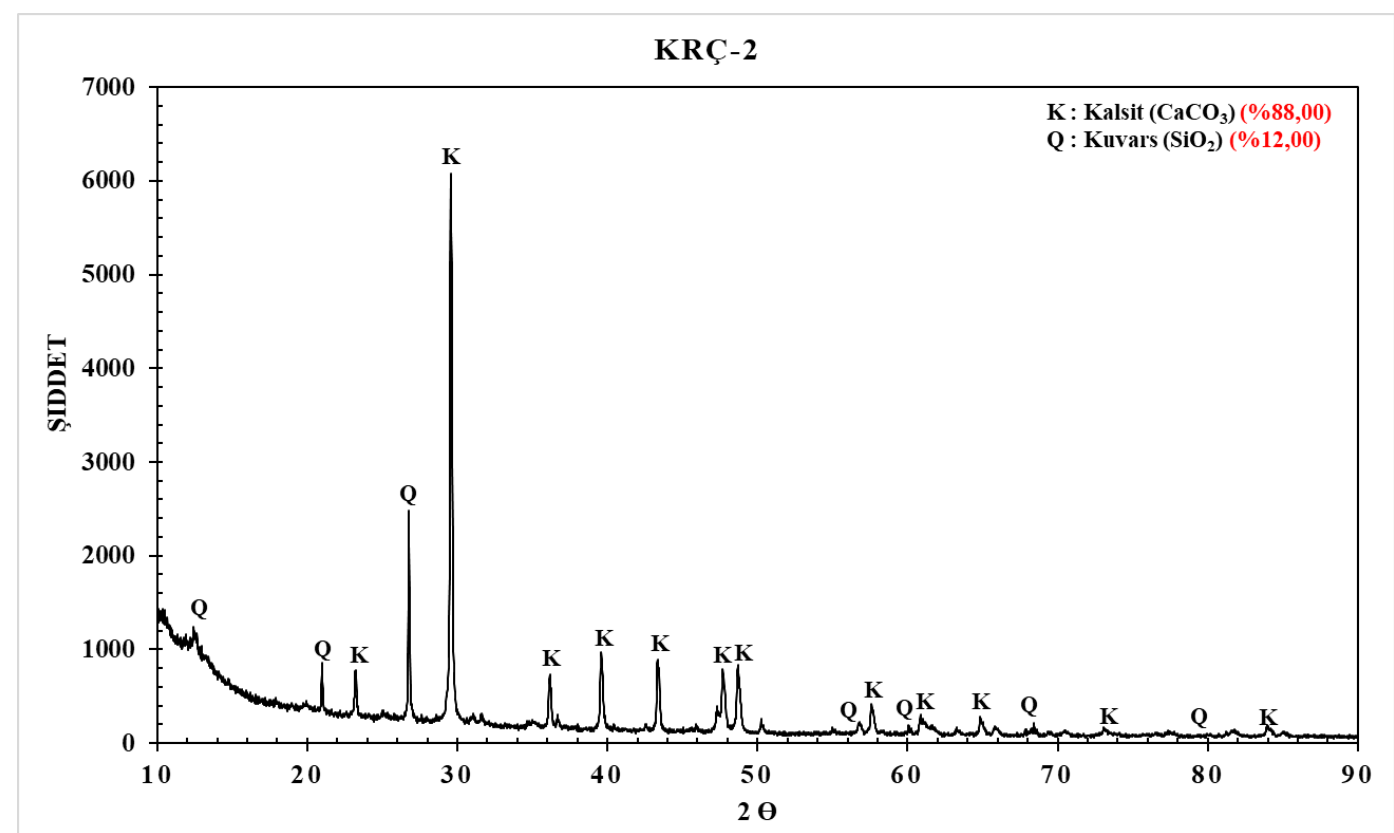

Şekil 7. KRÇ-2 numunesine ait XRD grafiği ve içeriği oluşturan minerallerin \% dağılımı Figure 7. The XRD graph of the KRÇ-2 sample and the \% distribution of the minerals that make up the content

\section{Kireçtaşlarının Kimyasal Özellikleri (Chemical Properties of Limestones)}

Kireçtaşlarının içerdiği ana element oksit bileşiklerini belirlemek amacıyla yapılan 2 adet kimyasal analiz sonuçları Çizelge 3'te verilmiştir. Bu çizelgeye göre kireçtaşlarında $\mathrm{CaO} \% 42.73-50.09$, A.Z (Ateş Zayiatı) \% 35.55 - 42.78 arasında değişmektedir. Kimyasal analiz verilerine göre, incelenen KRÇ1 numunesi $\mathrm{CaO}$ miktarı \%50'den fazla ve $\mathrm{MgO}$ miktarı \%2'den az olduğu için kireçtaşı, KRÇ2 ise $\mathrm{CaO}$ miktarı \%50'den ve $\mathrm{MgO}$ miktarı \%2'den az olması sebebiyle saf olmayan kireçtaşı olarak değerlendirilmektedir (Elçi ve diğ., 2014). Kireçtaşlarında az oran da $\mathrm{MgO}$ bulunması dolomitin, $\mathrm{Fe}_{2} \mathrm{O}_{3}$ bulunması ise pirit, hematit gibi demir minerallerinin bulunduğunu ifade etmektedir. $\mathrm{SiO}_{2}$ varlığı ise kil mineralleri ve kuvars minerallerinden kaynaklanmaktadır (Yılmaz ve diğ., 2011). Elde edilen sonuçlar mineralojik ve petrografik analizi desteklemektedir. Ayrıca beton agregası olarak kullanılacak kayaçların $\mathrm{MgO}$ oranının ise, \%3'ün altında olması istenmektedir.

Çizelge 3. Kireçtaşlarının kimyasal analiz sonucu kimyasal ana oksit yüzdeleri Table 3. Chemical main oxide percentages of limestones as a result of chemical analysis

\begin{tabular}{|c|c|c|c|c|c|c|c|c|}
\hline \multirow{2}{*}{$\begin{array}{c}\text { Örnek } \\
\text { Numaras1 }\end{array}$} & \multicolumn{7}{|c|}{ Bileşim (\%) } \\
\cline { 2 - 10 } & $\mathbf{C a O}$ & $\mathrm{SiO}_{2}$ & $\mathbf{A l}_{2} \mathbf{O}_{3}$ & $\mathbf{F e}_{2} \mathbf{O}_{3}$ & $\mathbf{M g O}$ & $\mathbf{K}_{2} \mathbf{O}$ & $\mathbf{N a}_{2} \mathbf{O}$ & ${ }^{*} \mathbf{A Z}$ \\
\hline KRÇ1 & 50.09 & 2.82 & 1.31 & 1.19 & 1.12 & 0.34 & 0.08 & 42.78 \\
\hline KRÇ2 & 42.73 & 12.00 & 4.39 & 2.20 & 1.04 & 1.20 & 0.12 & 35.55 \\
\hline
\end{tabular}

${ }^{*}$ AZ: Ateş Zayiatı

Kireçtaşı agregaların bünyesinde betonun katılaşmasına veya sertleşmesine zarar veren, betonun işlevselliğini azaltan kükürt, sülfat, klorür içerikleri ile humus muhtevası TS EN 1744-1+A1 (2013)' e uygun olarak kimyasal analizler ile belirlenmiştir (Tuğrul ve diğ., 2008). Bu zararlı kimyasal bileşenler ile ilgili veriler Çizelge 4'te sunulmuştur. Ayrıca humus muhtevası (organik madde tayini) deneyinde agrega numuneleri üzerindeki sıvının standart renk çözeltisine göre daha açık renkte olduğu için agrega numunesi önemli miktarda organik madde içermemektedir.

Agregaların suda çözülebilen klorür oranı \%0.001 olarak belirlenmiştir. TS EN 1744-1+A1 (2013) göre beton agregaların klorür oranının en fazla $\% 0.01$ olabileceği belirtilmiştir. Standartta betonda kullanılacak 
agregaların toplam kükürt içeriğinin \%1 den az olması istenmektedir. İncelenen agregaların kükürt içeriği bu değerin çok altında kaldığından zararsız niteliktedir.

Agregalarda bulunan sülfatlar, betonun toplam sülfat içeriğini arttırarak betonda zararlı etkilere sebep olabilir. Bu sülfat etkisi sonucu oluşan reaksiyon ürünleri sertleşmiş betonda genleşme oluşturarak agrega-çimento aderansının olumsuz yönde etkilenmesine, çatlak oluşumuna ve geçirimliliğin artmasına yol açmaktadır (Tosun ve diğ., 2003). İncelenen kireçtaşı agregaların asitte çözünen sülfat içeriği en düşük kategori olan $\mathrm{AS}_{0,2}(\% 0.2)^{\prime}$ den daha düşüktür.

Çizelge 4. Kireçtaşlarının bünyesinde bulunan zararlı kimyasal bileşenler Table 4. Harmful chemical components in limestones

\begin{tabular}{|c|c|c|c|c|}
\hline Deney Adı & $\begin{array}{l}\text { Agrega Boyutu } \\
\text { (mm) }\end{array}$ & $\begin{array}{c}\text { Numune } \\
\text { No }\end{array}$ & Deney Sonucu & $\begin{array}{c}\text { TS EN 1744-1+A1 } \\
\text { Standardi Kategori } \\
\text { Değerleri }\end{array}$ \\
\hline \multirow{2}{*}{$\begin{array}{l}\text { Asitte çözülen sülfat } \\
\text { içeriği }\left(\mathrm{SO}_{3}\right)(\%)\end{array}$} & \multirow{2}{*}{ 0-4 Kirma kum } & KRÇ 1 & 0.04 & \multirow{2}{*}{$<\% 1$} \\
\hline & & KRÇ 2 & 0.06 & \\
\hline \multirow{2}{*}{$\begin{array}{l}\text { Toplam kükürt içeriği } \\
\text { (S) (\%) }\end{array}$} & \multirow[b]{2}{*}{ 0-4 Kirma kum } & KRÇ 1 & 0.08 & \multirow{2}{*}{$<\% 1$} \\
\hline & & KRÇ 2 & 0.10 & \\
\hline \multirow[b]{2}{*}{ Klorür oranı $\left(\mathrm{Cl}^{-}\right)(\%)$} & \multirow[b]{2}{*}{ 0-4 Kirma kum } & KRÇ 1 & 0.001 & \multirow{2}{*}{$<\% 0.01$} \\
\hline & & KRÇ 2 & 0.001 & \\
\hline \multirow{2}{*}{ Humus Muhtevası } & \multirow{2}{*}{ 0-4 Kırma kum } & KRÇ 1 & Oluşan renk & \multirow{2}{*}{$\begin{array}{l}\text { Koyu Kırmızı renk } \\
\text { kullanılamaz. }\end{array}$} \\
\hline & & KRÇ 2 & \begin{tabular}{|c|} 
standart \\
renkten açıtır.
\end{tabular} & \\
\hline
\end{tabular}

Kireçtaşı Agregalarının Fiziksel Özellikleri (Physical Properties of Limestone Aggregates)

Tane büyüklüğü dağılımı tayini (Determination of grain size distribution)

Kireçtaşından elde edilen agregaların tane büyüklüğü dağılımını belirlemek amacıyla TS EN 933-1 (2012)'e göre elek analizi deneyi yapılmıştır. Agrega yığının gradasyonunun saptanmasında tane boyutu dağılımı (elek analizi) deneyi yaygın olarak kullanılmaktadır (Hasdemir, 2007). Elek analizlerinde 4 mm açıklı elekten geçen agregalar ince agrega, $4 \mathrm{~mm}$ açıklı elek üzerinde kalan agregalar ise iri agregalar olarak tanımlanmaktadır. Beton agregası olabilirliği incelenen Gebze Bölgesinden alınan kireçtaşı agregalarına ait granülometri eğrileri Şekil 8 ve Şekil 9'da sunulmuştur. Yapılan elek analizi sonuçlarına göre agregaların tane boyutu dağılımı her farklı agrega grubu için ideal bir izlenim vermektedir (Çizelge 5 ve Çizelge 6). 
Çizelge 5. İncelenen KRÇ-1 kireçtaşı agregalarının tane boyu dağılımı Table 5. Grain size distribution of investigated limestone aggregates KRÇ-1

\begin{tabular}{|c|c|c|c|c|c|c|c|c|c|c|c|c|}
\hline \multirow[b]{2}{*}{$\begin{array}{c}\text { Elek } \\
\text { Aralığ1 } \\
(\mathrm{mm})\end{array}$} & \multicolumn{3}{|c|}{$\begin{array}{c}\text { Kirma kum } \\
(0-4 \mathrm{~mm})\end{array}$} & \multicolumn{3}{|c|}{$\begin{array}{c}\text { Yıkanmış Kırma kum } \\
(0-4 \mathrm{~mm})\end{array}$} & \multicolumn{3}{|c|}{$\begin{array}{c}\text { Kırmataş } 1 \\
(4-12 \mathrm{~mm})\end{array}$} & \multicolumn{3}{|c|}{$\begin{array}{l}\text { Kırmataş } 2 \\
(12-22 \mathrm{~mm})\end{array}$} \\
\hline & $\begin{array}{c}\text { Küm. } \\
\text { Kalan (g) }\end{array}$ & $\begin{array}{c}\% \\
\text { Kal } \\
\text { an }\end{array}$ & $\begin{array}{c}\% \\
\text { Geç } \\
\text { en }\end{array}$ & $\begin{array}{l}\text { Küm. } \\
\text { Kalan (g) }\end{array}$ & $\begin{array}{c}\% \\
\text { Kal } \\
\text { an }\end{array}$ & $\begin{array}{l}\% \\
\text { Geç } \\
\text { en }\end{array}$ & $\begin{array}{l}\text { Küm. } \\
\text { Kalan (g) }\end{array}$ & $\begin{array}{c}\% \\
\text { Kal } \\
\text { an }\end{array}$ & $\begin{array}{c}\% \\
\text { Geç } \\
\text { en }\end{array}$ & $\begin{array}{l}\text { Küm. } \\
\text { Kalan (g) }\end{array}$ & $\begin{array}{c}\% \\
\text { Kal } \\
\text { an }\end{array}$ & $\begin{array}{l}\% \\
\text { Geç } \\
\text { en }\end{array}$ \\
\hline 22,4 & - & - & 100 & - & - & 100 & - & - & 100 & - & - & 100 \\
\hline 16 & - & - & 100 & - & - & 100 & - & - & 100 & 385 & $\begin{array}{c}29.0 \\
7\end{array}$ & 71 \\
\hline 11,2 & - & - & 100 & - & - & 100 & 18 & 1.36 & 99 & 823 & $\begin{array}{c}91.2 \\
3 \\
\end{array}$ & 9 \\
\hline 8 & - & - & 100 & - & - & 100 & 435 & $\begin{array}{c}34.4 \\
1\end{array}$ & 66 & - & - & 0 \\
\hline 5,6 & 12 & 0.96 & 99 & - & - & 100 & 667 & $\begin{array}{c}85.0 \\
9\end{array}$ & 15 & - & - & 0 \\
\hline 4 & 168 & $\begin{array}{c}14.4 \\
3\end{array}$ & 86 & - & - & 100 & 174 & $\begin{array}{c}98.3 \\
1\end{array}$ & 2 & - & - & 0 \\
\hline 2 & 372 & $\begin{array}{c}44.2 \\
6\end{array}$ & 56 & 169 & $\begin{array}{c}13.9 \\
4\end{array}$ & 86 & 14 & $\begin{array}{l}99.3 \\
7\end{array}$ & 1 & - & - & 0 \\
\hline 1 & 263 & $\begin{array}{c}65.3 \\
5 \\
\end{array}$ & 35 & 367 & $\begin{array}{c}44.2 \\
2 \\
\end{array}$ & 56 & - & - & 0 & - & - & 0 \\
\hline 0,5 & 168 & $\begin{array}{c}78.8 \\
2 \\
\end{array}$ & 21 & 257 & $\begin{array}{c}65.4 \\
2 \\
\end{array}$ & 35 & - & - & 0 & - & - & 0 \\
\hline 0,25 & 98 & $\begin{array}{c}86.6 \\
7 \\
\end{array}$ & 13 & 170 & $\begin{array}{c}79.4 \\
4 \\
\end{array}$ & 21 & - & - & 0 & - & - & 0 \\
\hline 0,125 & 34 & $\begin{array}{c}89.3 \\
9 \\
\end{array}$ & 11 & 115 & $\begin{array}{c}88.9 \\
2 \\
\end{array}$ & 11 & - & - & 0 & - & - & 0 \\
\hline 0,063 & 30 & $\begin{array}{c}91.7 \\
9\end{array}$ & 8 & 64 & 94.2 & 6 & - & - & 0 & - & - & 0 \\
\hline $\begin{array}{l}\text { Toplam } \\
\text { (g) }\end{array}$ & 1247 & & & 1212 & & & 1316 & & & 1324 & & \\
\hline
\end{tabular}

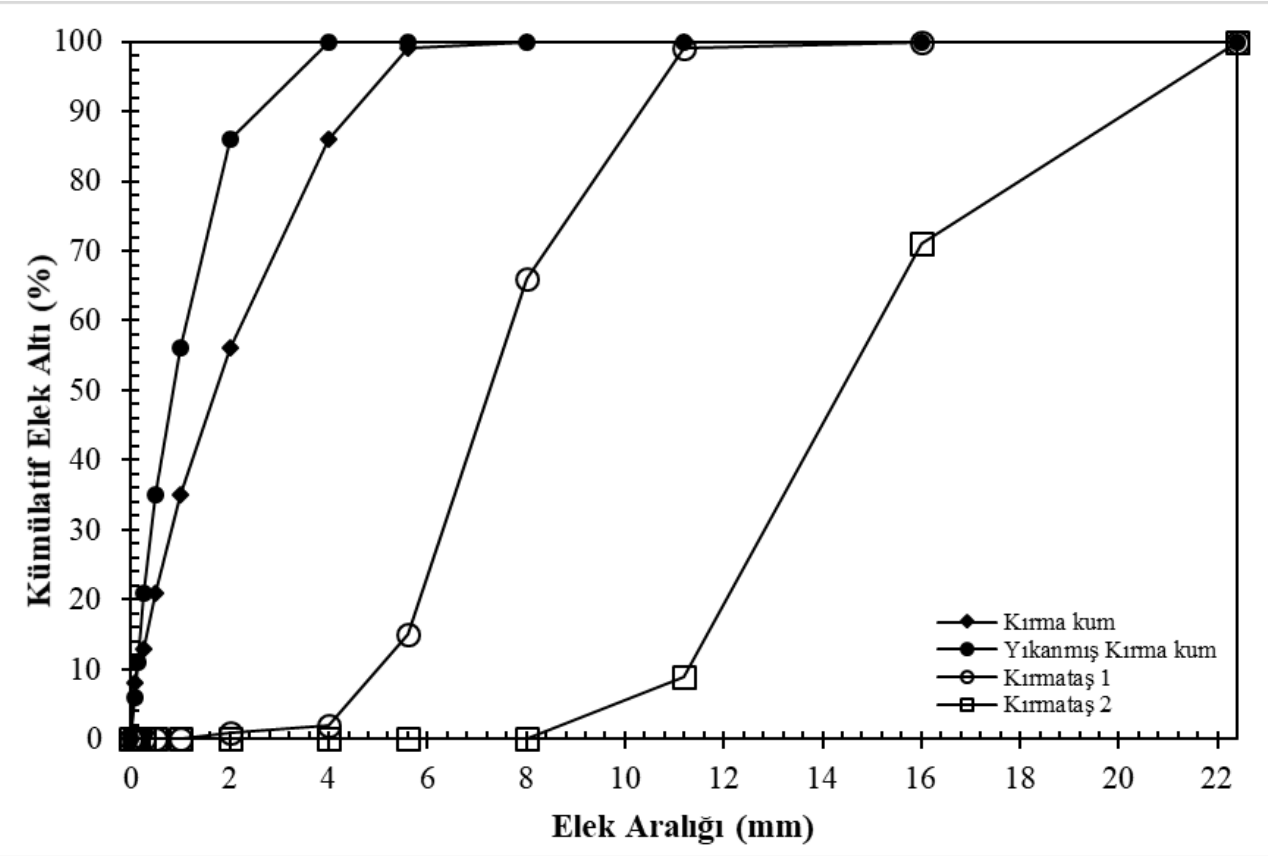

Şekil 8. İncelenen KRÇ-1 kireçtaşı agregalarının granülometri eğrisi Figure 8. The grading curve of the investigated limestone aggregates KRÇ-1 
Çizelge 6. İncelenen KRÇ-2 kireçtaşı agregalarının tane boyu dağılımı Table 6. Grain size distribution of investigated limestone aggregates $K R C ̧-2$

\begin{tabular}{|c|c|c|c|c|c|c|c|c|c|c|c|c|}
\hline \multirow[b]{2}{*}{$\begin{array}{c}\text { Elek } \\
\text { Aralığ1 } \\
\text { (mm) }\end{array}$} & \multicolumn{3}{|c|}{$\begin{array}{c}\text { Kirma kum } \\
(0-4 \mathrm{~mm})\end{array}$} & \multicolumn{3}{|c|}{$\begin{array}{c}\text { Yıkanmış Kırma kum } \\
(0-4 \mathrm{~mm})\end{array}$} & \multicolumn{3}{|c|}{$\begin{array}{c}\text { Kirmataş } 1 \\
(4-12 \mathrm{~mm})\end{array}$} & \multicolumn{3}{|c|}{$\begin{array}{l}\text { Kirmataş } 2 \\
(12-22 \mathrm{~mm})\end{array}$} \\
\hline & $\begin{array}{c}\text { Küm. } \\
\text { Kalan } \\
\text { (g) }\end{array}$ & $\begin{array}{c}\% \\
\text { Kalan }\end{array}$ & $\begin{array}{c}\% \\
\text { Geçen }\end{array}$ & $\begin{array}{l}\text { Küm. } \\
\text { Kalan } \\
\text { (g) }\end{array}$ & $\begin{array}{c}\% \\
\text { Kalan }\end{array}$ & $\begin{array}{c}\% \\
\text { Geçen }\end{array}$ & $\begin{array}{l}\text { Küm. } \\
\text { Kalan } \\
\text { (g) }\end{array}$ & $\begin{array}{c}\% \\
\text { Kalan }\end{array}$ & $\begin{array}{c}\% \\
\text { Geçen }\end{array}$ & $\begin{array}{l}\text { Küm. } \\
\text { Kalan } \\
\text { (g) }\end{array}$ & $\begin{array}{c}\% \\
\text { Kalan }\end{array}$ & $\begin{array}{c}\% \\
\text { Geçen }\end{array}$ \\
\hline 22,4 & - & - & 100 & - & - & 100 & - & - & 100 & - & - & 100 \\
\hline 16 & - & - & 100 & - & - & 100 & - & - & 100 & 685 & 53.34 & 47 \\
\hline 11,2 & - & - & 100 & - & - & 100 & 271 & 20.40 & 80 & - & - & 0 \\
\hline 8 & - & - & 100 & - & - & 100 & 744 & 76.42 & 24 & - & - & 0 \\
\hline 5,6 & - & - & 100 & - & - & 100 & 265 & 96.37 & 4 & - & - & 0 \\
\hline 4 & 115 & 9.39 & 91 & - & - & 100 & - & - & 0 & - & - & 0 \\
\hline 2 & 319 & 35.45 & 65 & 124 & 10.03 & 90 & - & - & 0 & - & - & 0 \\
\hline 1 & 244 & 55.38 & 45 & 323 & 36.16 & 64 & - & - & 0 & - & - & 0 \\
\hline 0,5 & 171 & 69.35 & 31 & 418 & 69.97 & 30 & - & - & 0 & - & - & 0 \\
\hline 0,25 & 111 & 78.41 & 22 & 117 & 79.43 & 21 & - & - & 0 & - & - & 0 \\
\hline 0,125 & 99 & 86.49 & 14 & 65 & 84.68 & 15 & - & - & 0 & - & - & 0 \\
\hline 0,063 & 57 & 91.14 & 9 & 63 & 89.77 & 10 & - & - & 0 & - & - & 0 \\
\hline $\begin{array}{l}\text { Toplam } \\
\text { (g) }\end{array}$ & 1224 & & & 1236 & & & 1328 & & & 1284 & & \\
\hline
\end{tabular}

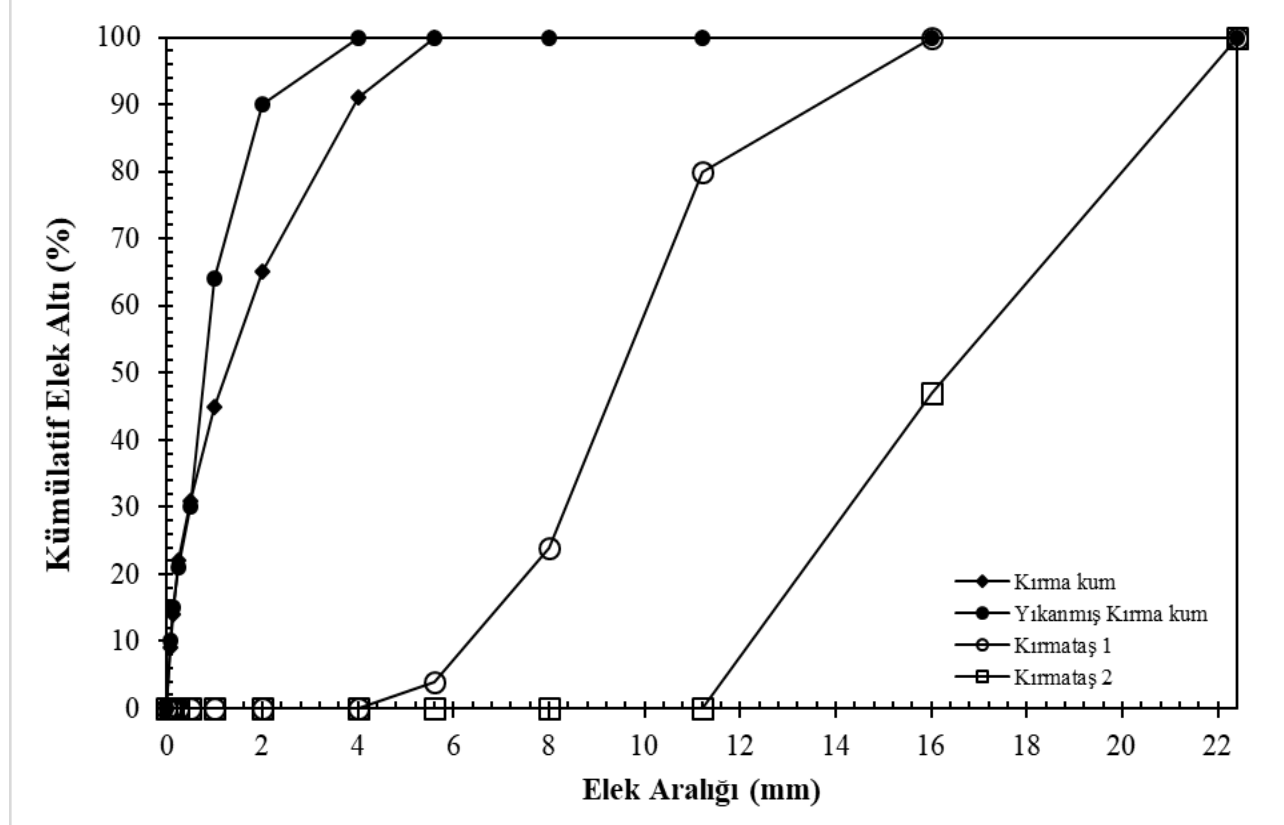

Şekil 9. İncelenen KRÇ-2 kireçtaşı agregalarının granülometri eğrisi Figure 9. The grading curve of the investigated limestone aggregates KRÇ-2 
Çok ince malzeme muhtevası (Fine content)

Çok ince malzeme muhtevası; agrega içerisindeki TS 933-1 (2012) standardına göre tane büyüklüğü $0.063 \mathrm{~mm}$ den geçen malzeme miktarı olarak tanımlanır. İnce malzemeler betonda birçok olumsuzluğa sebep olabilmektedir.

Çok ince malzemeler agrega tanelerinin etrafını sararak çimento hamuru ile arasındaki aderansın azalmasına neden olmaktadır (Fookes, 1980). Beton üretiminde karma suyu miktarını artırarak betonun dayanım ve durabilitesine olumsuz etki etmektedir (Erdoğan, 2003). Bu nedenle, çok ince madde oranıyla birlikte bu malzemenin kalitesinin de belirlenmesi gerekmektedir.

TS 706 EN 12620 (2003) Standardında ince agregalarda çok ince madde oranı \% 3'ü, iri agregalarda ise \%1'i aştığında bunların kalitesinin belirlenmesi gerektiği ifade edilmektedir. İncelenen agregaların çok ince madde miktarının (0,063mm geçen) ince agregalarda (kırma kum, yıkanmış kırma kum) \%3' den fazla olduğu, iri agregaların (kırmataş 1, kırmataş 2) ise \%1' den az olduğu tespit edilmiştir (Çizelge 5 ve Çizelge $6)$.

\section{Metilen mavisi deneyi (methylene blue test)}

Metilen mavisi deneyi, ince agrega içindeki kil, demir oksit ve organik madde miktarını sınırlandırmak için kullanılan, deney yöntemidir. Yöntem özel ekipman gerektirmediği ve kolay uygulanışı ile beton üretiminde yaygın kullanılmaktadır.

İnce agregalar üzerinde yapılan metilen mavisi deneyi TS EN 933-9+A1 (2014) uygun olarak yapılmış sonuçları Çizelge 7' de verilmiştir. Metilen mavisi sonuçları ortalama olarak kırma kum $1 \mathrm{~g} / \mathrm{kg}$ ve yıkanmış kırma kum ise $0.50 \mathrm{~g} / \mathrm{kg}^{\prime}$ dır. Metilen mavisi sonuçlarının belli bir standardı olmamak ile birlikte sonuçların $2.50 \mathrm{~g} / \mathrm{kg}$ değerini aşmaması istenmektedir. KRÇ-1 ve KRÇ-2 numunelerine yapılan metilen mavisi deneyinde elde edilen değerlerin sınır değerin $(\% 2,5)$ altında olduğu ve beton agregası olarak kullanılabileceği saptanmıştır.

Çizelge 7. Kireçtaşı agrega numunelerine ait metilen mavisi değerleri

\begin{tabular}{|c|c|c|c|c|c|}
\hline $\begin{array}{c}\text { Agrega } \\
\text { Boyutu (mm) }\end{array}$ & $\begin{array}{c}\text { Numune } \\
\text { No }\end{array}$ & $\begin{array}{c}\text { Deney } \\
\text { Numunesi } \\
\text { Miktarı (g) }\end{array}$ & $\begin{array}{c}\text { Ilave Edilen } \\
\text { Metilen } \\
\text { Mavisi } \\
\text { Çözeltisi (ml) }\end{array}$ & $\begin{array}{c}\text { Metilen } \\
\text { Mavisi Değeri } \\
\text { (MB) (\%) }\end{array}$ & $\begin{array}{c}\text { Metilen } \\
\text { Mavisi Sınır } \\
\text { Değeri (MB) } \\
(\%)\end{array}$ \\
\hline 0-4 kuru & KRÇ-1 & 200 & 20 & 1.00 & \\
\hline 0-4 kuru & KRÇ-2 & 200 & 20 & 1.00 & \multirow{2}{*}{2.5} \\
\hline 0-4 yıkanmış & KRÇ-1 & 200 & 10 & 0.50 & \\
\hline $0-4$ yıkanmiş & KRÇ-2 & 200 & 10 & 0.50 & \\
\hline
\end{tabular}

\section{Tane yoğunluğu ve su emme oranının tayini (Determination of particle density and water absorption rate)}

Tane yoğunluğu (özgül ağırlık) ve su emme deneyleri TS EN 1097-6 (2013) uygun olarak yapılmıştır. Agregaların tane yoğunluğu ve su emme oranı beton karışım hesaplarında kullanılmaktadır. İnce agregaların su emmesi iri agregalara göre yüksek değerler vermiştir. Özgül ağırlığın ise birbirine yakın değerlerde olduğu görülmektedir (Çizelge 8). Bu değerler agregaların özgül ağırlıklarının, normal beton değerlerinin içerisinde yer aldığını göstermektedir. 
Çizelge 8. Kireçtaşı agregaların ortalama tane yoğunlukları ve su emme oranları Table 8. Mean particle densities and water absorption rates of limestone aggregates

\begin{tabular}{|c|c|c|c|}
\hline $\begin{array}{c}\text { Agrega Boyutu } \\
(\mathbf{m m})\end{array}$ & $\begin{array}{c}\text { Numune } \\
\text { No }\end{array}$ & $\begin{array}{c}\text { Doygun Yüzey Kuru Tane } \\
\left.\text { Yoğunluğu } \mathbf{( M g} / \mathbf{m}^{\mathbf{3}}\right)\end{array}$ & $\begin{array}{c}\text { Su Emme } \\
\text { Oran1 (\%) }\end{array}$ \\
\hline $0-4$ kuru & KRÇ-1 & 2.71 & 1.0 \\
\hline $0-4$ kuru & KRÇ-2 & 2.67 & 1.2 \\
\hline $0-4$ yıkanmış & KRÇ-1 & 2.70 & 1.4 \\
\hline $0-4$ y1kanmış & KRÇ-2 & 2.68 & 1.8 \\
\hline $4-12$ & KRÇ-1 & 2.72 & 0.5 \\
\hline $4-12$ & KRÇ-2 & 2.68 & 0.7 \\
\hline $12-22$ & KRÇ-1 & 2.73 & 0.4 \\
\hline $12-22$ & KRÇ-2 & 2.69 & 0.6 \\
\hline
\end{tabular}

Agregaların su emme değerleri don etkilerinin tespitinde etkili bir değerlendirme ölçütü olarak yoğun bir şekilde kullanılmaktadır. Diğer yandan beton karışımlarında karma suyunu etkilemesi ve betonun dayanımını düşürmesi sebebiyle önem kazanmaktadır.

Agrega numunelerinin su emme değerleri ortalama olarak ince agregalar \%1.1-\%1.6 ve iri agregalarda $\% 0.5-\% 0.6$ olduğu belirlenmiştir. Betonda kullanılacak agreganın su emme değerinin \% 3'den az olması istenmektedir (TS 706 EN 12620, 2003). İncelenen agregaların su emme değerlerinin standartlara uygun olduğu görülmektedir (Çizelge 8).

\section{Yassılık endeksi (Flakiness index)}

Beton içerisinde kullanılan agregaların en az boşluk oluşturacak şekilde olması istenir. Bu yüzden agrega tanelerinin şekli, olabildiğince küresel ve kübik olmalıdır. Böylece agrega yığını daha iyi bir biçimde yerleşerek taneler arası boşluklar en aza iner. Beton içerisinde yer alan yassı taneler, kolaylıkla çimento ile bağ kurabildiği gibi karışım içerisindeki bazı yassı taneler, yığın içerisinde açık boşluklar oluşturabilmektedir (Elçi, 2011). Bu boşluklar betondaki çimento ihtiyacını artıracağı için yassı tanelerin varlığını tespit etmek önem teşkil etmektedir.

Kireçtaşı iri agregalar (4-12 mm ve 12-22 mm) üzerinde yapılan yassılık endeksi deneyi TS EN 933-3 (2012) uygun olarak yapılmış deney sonuçları Çizelge 9' de belirtilmiştir. Deney sadece 4-80 mm arasında tane boyutuna sahip agregalarda uygulanmaktadır (Çelik ve diğ., 2018). Betonun işlenebilirliği, su gereksinimi ve betonun iyi yerleşebilmesi açısından yassılık endeksinin $\% 20$ değerini geçmemesi iyi sayılmaktadır (Keskin, 2011).

Çizelge 9. Kireçtaşı agregalarının yassılık endeksi değerleri

Table 9. Flakiness index values of limestone aggregates

\begin{tabular}{|c|c|c|c|c|}
\hline $\begin{array}{c}\text { Agrega } \\
\text { Boyutu (mm) }\end{array}$ & $\begin{array}{c}\text { Numune } \\
\text { No }\end{array}$ & $\begin{array}{c}\text { Deneye Giren } \\
\text { Toplam } \\
\text { Malzeme } \\
\text { Miktarı (g) }\end{array}$ & $\begin{array}{c}\text { Yassı } \\
\text { Malzeme } \\
\text { Miktarı (g) }\end{array}$ & $\begin{array}{c}\text { Yassılık } \\
\text { Endeksi } \\
\text { Değeri (\%) }\end{array}$ \\
\hline $4-12$ & KRÇ-1 & 1595 & 268 & 16.8 \\
\hline $4-12$ & KRÇ-2 & 1640 & 282 & 17.2 \\
\hline $12-22$ & KRÇ-1 & 1543 & 196 & 12.7 \\
\hline $12-22$ & KRÇ-2 & 1624 & 216 & 13.3 \\
\hline
\end{tabular}

Deney sonucunda kırmataş 1 (4-12 mm) agregaların ortalama yassılık endeksinin \%17 ve kırmataş 2 $(12-22 \mathrm{~mm})$ agregaların ise ortalama yassılık endeksinin \%13 olarak bulunmuştur. Kireçtaşı agregaların 
ortalama yassılık endeksi değerinin TS 706 EN 12620 (2003) standardı açısından en uygun alan olan $\boldsymbol{F I}_{15}$ kategorisinde yer aldığ belirlenmiştir.

\section{Kireçtaşı Agregalarının Mekanik Özellikleri (Mechanical Properties of Limestone Aggregates)}

\section{Parçalanma direncinin tayini (Los Angeles) (Determination of resistance to fragmentation)}

$\mathrm{Bu}$ testte agreganın darbeye karşı dayanımını saptamak amacıyla yapılan bir dayanım testidir. Özellikle dinamik baskıların yüksek olduğu alanlarda beton agregası olarak kullanılacak betonun aşınması açısından büyük önem taşımaktadır. Agregaların darbeye karşı dayanımı ve aşınabilirliğini belirlemek amacıyla TS EN 1097-2 (2010) standardına göre “Los Angeles Aşınma Deneyi“ yapılır. Kireçtaşı iri agregalar üzerinde parçalanma direncinin tayini için Los Angeles deneyi TS EN 1097-2 (2010) uygun olarak yapılmış ve elde edilen deney sonuçları Çizelge 10'de verilmiştir.

Çizelge 10. Kireçtaşı agregalarının Los Angeles deneyi ile parçalanmaya karşı direncin tayini Table 10. Determination of resistance to disintegration of limestone aggregates by Los Angeles test

\begin{tabular}{|c|c|c|c|c|}
\hline $\begin{array}{c}\text { Agrega Boyutu } \\
(\mathbf{m m})\end{array}$ & $\begin{array}{c}\text { Numune } \\
\text { No }\end{array}$ & $\begin{array}{c}\text { Numunenin } \\
\text { Başlangıç Kuru } \\
\text { Ağırlığı, g }\end{array}$ & $\begin{array}{c}\mathbf{1 , 6} \text { mm Elek } \\
\text { Üstü Malzeme } \\
\text { Miktarı, g }\end{array}$ & $\begin{array}{c}\text { Los Angeles } \\
\text { Katsayısı } \\
\text { (LA) (\%) }\end{array}$ \\
\hline $4-12$ & KRÇ-1 & 5000 & 4061 & 19.3 \\
\hline $4-12$ & KRÇ-2 & 5000 & 4042 & 18.7 \\
\hline $12-22$ & KRÇ-1 & 5000 & 4030 & 19.4 \\
\hline $12-22$ & KRÇ-2 & 5000 & 4068 & 18.6 \\
\hline
\end{tabular}

Beton agregalarında TS EN Standartlarına göre Los Angeles parçalanma oranının \%50'yi geçmemesi istenmektedir. İncelenen iri agregaların ortalama Los Angeles parçalanma deneyi 500 devirde \%19 kayıp bulunmuştur. Bu değer agregaların parçalanma deneyi açısından son derece uygun olan LA20 kategorisinde olduğunu göstermektedir. Elde edilen sonuca göre agregaların beton agregası olarak değerlendirile bilir özellikte olduğu söylenebilir.

\section{Aşınmaya Karşı Direnç (Mikro-Deval Katsayısı) (Abrasion Resistance)}

Mikro-Deval aşınma deneyi, iri agregaların bir miktar su katılarak tamburda çelik bilyeler ile dönmesi sonucu 1,6 mm açıklıklı eleğin üzerinde kalan malzemenin yüzdesini belirlemek için kullanılan yöntemdir (TS EN 1097-1, 2011). Kireçtaşı agregalarının aşınmaya karşı direncini belirlemek için Mikro-Deval deneyi TS EN 1097-1 (2011) uygun olarak yapılmış deney sonuçları Çizelge 11'de belirtilmiştir.

Çizelge 11. Kireçtaşı agregalarının Mikro-Deval aşınma değerleri Table 11. Micro-Deval abrasion values of limestone aggregates

\begin{tabular}{|c|c|c|c|c|}
\hline $\begin{array}{c}\text { Agrega } \\
\text { Boyutu (mm) }\end{array}$ & $\begin{array}{c}\text { Numune } \\
\text { No }\end{array}$ & $\begin{array}{c}\text { Numunenin } \\
\text { Başlangıç } \\
\text { Kuru } \\
\text { Ağırlığı (g) }\end{array}$ & $\begin{array}{c}\mathbf{1 , 6 ~ m m ~ E l e k ~} \\
\text { Üstü } \\
\text { Malzeme } \\
\text { Miktarı, g }\end{array}$ & $\begin{array}{c}\text { Mikro-Deval } \\
\text { Katsayısı } \\
\text { (MDE) (\%) }\end{array}$ \\
\hline $4-12$ & KRÇ-1 & 5000 & 4118 & 18.4 \\
\hline $4-12$ & KRÇ-2 & 5000 & 4078 & 17.6 \\
\hline $12-22$ & KRÇ-1 & 5000 & 4086 & 18.3 \\
\hline $12-22$ & KRÇ-2 & 5000 & 4115 & 17.7 \\
\hline
\end{tabular}

İri agregaların TS EN Standartlarına göre Mikro-Deval aşınmaya karşı direncin \%35 den az olması istenmektedir. Aşınma dayanım değeri ne kadar az ise tanelerin mekanik etkilere karşı dayanımı o derece 
yüksek kabul edilmektedir. İncelenen iri agregaların ortalama olarak aşınmaya karşı direncinin \% 18 olduğu görülmektedir (Çizelge 11). Bu değerler ile agregalar aşınma deneyi açısından $M_{D E 20}$ kategorisinde yer almaktadır. Elde edilen veriler kireçtaşının aşınmaya ve parçalanmaya karşı direncinin uygun olduğunu göstermektedir.

\section{Alkali-Silis Reaksiyonu (Alkali-Silica Reaction)}

Petrografik araştırmalarda incelenen kireçtaşlarının içerisinde aktif silis içeren mineraller bulunmaktadır. Bu minerallerin fazla bulunması ve ortamın rutubetli olması betonda alkali-silika reaksiyon riskini oluşturabilir. Agrega alıcıları olan beton firmaları kireçtaşının içerisindeki aktif silis oranını belirlemek istedikleri için bu deney yapılmaktadır. Bu sebeple, kireçtaşı numuneleri ile ASTM C 1260-14 (2014) standardına uygun olarak hızlandırılmış harç çubuğu deneyleri yapılmıştır. Deneyler ile kireçtaşı agregalarının çimento hamuru ile oluşturabileceği reaksiyon sonucu genleşmelerine bağlı boy uzamaları belirlenmiştir (Şekil 10). Deneylerde TS EN 197-1 (2012) standardına uygunluk gösteren CEMI 42,5 türü çimento kullanılmış ve kimyasal, fiziksel ve mekanik özellikleri Çizelge 12 'de verilmiştir. Deneyler üç numune üzerinde yapılmış olup, 3, 7 ve 14 günlük ortalama boy uzama oranları belirlenmiştir (Çizelge 13).

Çizelge 12. Deneylerde kullanılan çimentonun özellikleri

Table 12. Properties of the cement used in the experiments

\begin{tabular}{|c|c|c|c|}
\hline \multicolumn{2}{|l|}{ Kimyasal Özellikler } & \multicolumn{2}{|l|}{ Fiziksel Özellikler } \\
\hline $\mathrm{SiO}_{2}(\%)$ & 18.70 & Özgül Ağırlık (gr/cm³) & 3.11 \\
\hline $\mathrm{Al}_{2} \mathrm{O}_{3}(\%)$ & 4.90 & Özgül Yüzey (Blaine) $\left(\mathrm{cm}^{2} / \mathrm{gr}\right)$ & 3810 \\
\hline $\mathrm{Fe}_{2} \mathrm{O}_{3}(\%)$ & 3.31 & Hacim Genleşmesi (Le Chatelier) (mm) & 1 \\
\hline $\mathrm{CaO}(\%)$ & 63.51 & Priz Başlama Süresi (dk.) & 137 \\
\hline $\mathrm{MgO}(\%)$ & 1.34 & Priz Sona Erme Süresi (dk.) & 216 \\
\hline $\mathrm{SO}_{3}(\%)$ & 3.29 & İncelik $(45 \mu \mathrm{m})(\%)$ & 3.1 \\
\hline $\mathrm{Cl}(\%)$ & 0.03 & İncelik $(90 \mu \mathrm{m})(\%)$ & 0.2 \\
\hline $\mathrm{Na}_{2} \mathrm{O}(\%)$ & 0.20 & \multicolumn{2}{|l|}{ Basınç Dayanımı (MPa) } \\
\hline $\mathrm{K}_{2} \mathrm{O}(\%)$ & 0.83 & 2 Gün & 39 \\
\hline Çözünmeyen Kalıntı (\%) & 0.49 & 7 Gün & 53.4 \\
\hline Kızdırma Kaybı (\%) & 3.45 & 28 Gün & 61.9 \\
\hline
\end{tabular}


Çizelge 13. Kireçtaşının genleşmeye bağlı boy uzama oranları Table 13. Lengthening rates of limestone due to expansion

\begin{tabular}{|c|c|c|c|c|c|}
\hline $\begin{array}{c}\text { Zaman } \\
\text { (Gün) }\end{array}$ & $\begin{array}{c}\text { 1.Çubuk } \\
\text { Uzama } \\
\text { Oranı (\%) }\end{array}$ & $\begin{array}{l}\text { 2.Çubuk } \\
\text { Uzama } \\
\text { Oranı (\%) }\end{array}$ & $\begin{array}{c}\text { 3.Çubuk } \\
\text { Uzama } \\
\text { Oranı (\%) }\end{array}$ & $\begin{array}{c}\text { Ortalama } \\
\text { Uzama } \\
\text { Oranı (\%) }\end{array}$ & $\begin{array}{c}\text { ASTM C } 1260 \\
\text { Standardı Sınır } \\
\text { Değerleri }\end{array}$ \\
\hline 3 & 0.01 & 0.01 & 0.01 & 0.01 & $\begin{array}{c}\text { Ortalama Uzama } \\
\text { Oranı }>0,20 \text { Zararlı } \\
\text { agregalar }\end{array}$ \\
\hline 7 & 0.03 & 0.03 & 0.02 & 0.03 & \begin{tabular}{|c|} 
Ortalama Uzama \\
Oranı $>0,20$ Zararlı \\
agregalar
\end{tabular} \\
\hline 14 & 0.06 & 0.06 & 0.05 & 0.06 & \begin{tabular}{|c|} 
Ortalama Uzama \\
Oranı $>0,20$ Zararlı \\
agregalar
\end{tabular} \\
\hline
\end{tabular}

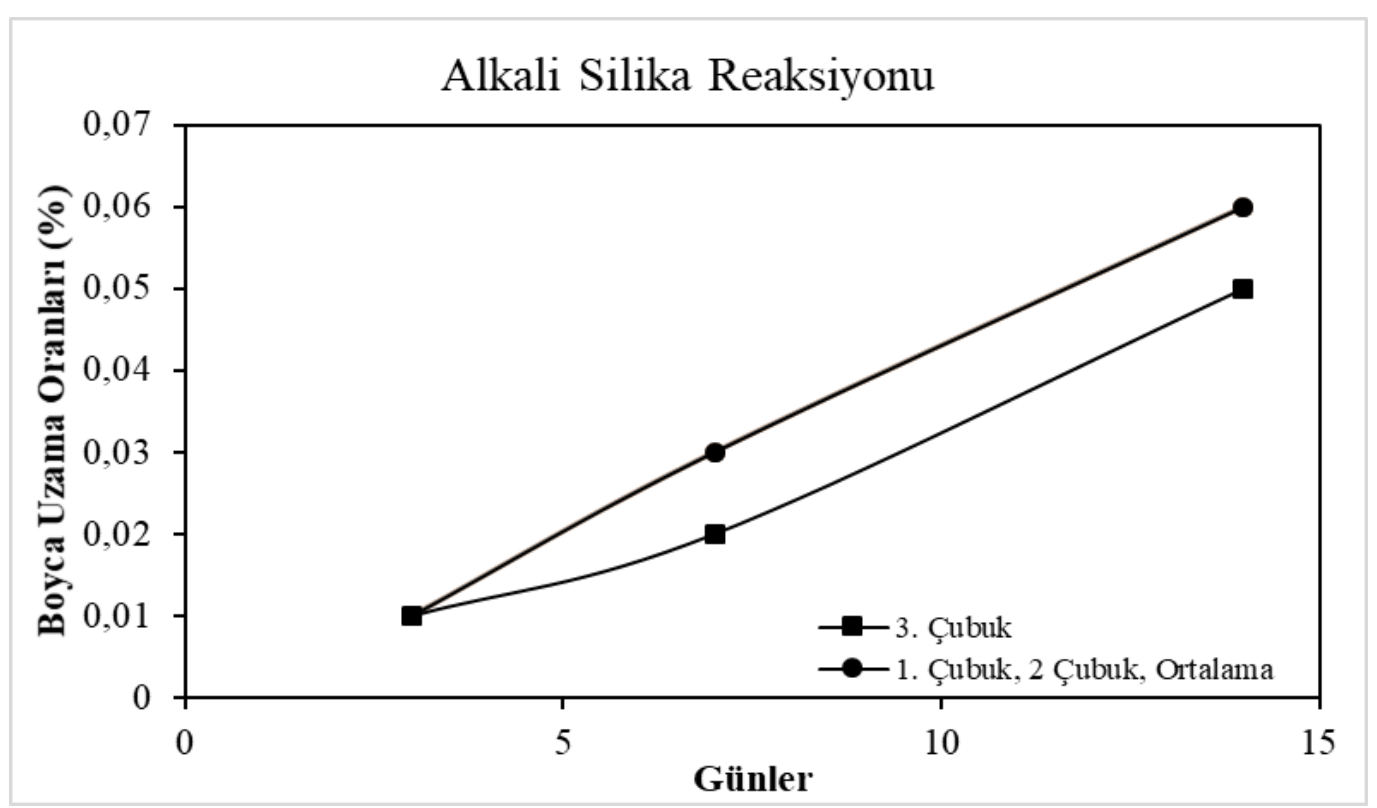

Şekil 10. Kireçtaşının genleşmeye bağlı boy uzamalarının karşılaştırılması Figure 10. Comparison of limestone growth rates due to expansion

Grafikte de görüldüğü gibi 3, 7 ve 14 günlük boy uzama oranları 1.Çubuk, 2.Çubuk ve Ortalama Uzama Oranların da aynı değerler ölçülmüştür (Şekil 10). ASTM C 1260-14 (2014) Standardı; harçların 14 gün sonunda boy uzamaları (genleşmeleri) \%0.20'den büyük ise incelenen agreganın alkali reaktivitesi bakımından zararlı olabileceğini belirtmektedir. Deney sonuçları ortalama boy uzama oranının \%0.10'un altında kaldığından alkali silika reaksiyonu yönünden zararsız niteliktedir.

\section{Taze ve Sertleşmiş Beton Özellikleri (Fresh and Hardened Concrete Properties)}

İncelenen Gebze kireçtaşı agregalarının özellikleri birbirine yakın değerler de olduğu için beton araştırmalarında, kireçtaşları agregaları ayrım yapılmadan üretimde kullanılmıştır. Gebze kireçtaşlarından elde edilen ince ve iri agregaların beton özelliklerine etkilerini araştırmak amacıyla laboratuvar ortamında 4 seriden oluşan deneme betonları üretilmiştir. Taze betonda yapılan deneyler; çökme deneyi ve birim ağırlık, sertleşmiş beton üzerinde ise beton basınç dayanımı deneyi yapılmıştır. 
Çalışma kapsamında incelenen kireçtaşı agregaları kullanılarak, çimento dozajları farklı $\left(275 \mathrm{~kg} / \mathrm{m}^{3}\right.$, $325 \mathrm{~kg} / \mathrm{m}^{3}, 345 \mathrm{~kg} / \mathrm{m}^{3}$ ve $395 \mathrm{~kg} / \mathrm{m}^{3}$ ) dört beton karışımı hazırlanmıştır (Çizelge 14). Karışım için en ideal granülometri seçilmiş, aynı tür çimento ve doğal kum kullanılarak farklı su/çimento oranına sahip dört farklı deneme betonu üretilmiştir. Deneme betonlarda kullanılan agrega karışım oranları Şekil 11'de verilmiştir. Çalışmalarda bağlayıcı malzeme olarak TS EN 197-1 (2012) standardına uygunluk gösteren CEM-I 42,5 türü çimento kullanılmıştır. Bu çimentonun kimyasal, fiziksel ve mekanik özellikleri Çizelge 12 'de verilmiştir. Beton karışımda işlenebilme ve dayanım özelliklerini geliştirebilmek amacıyla süper akışkanlaştırıcı kimyasal katkı malzemesi kullanılmıştır.

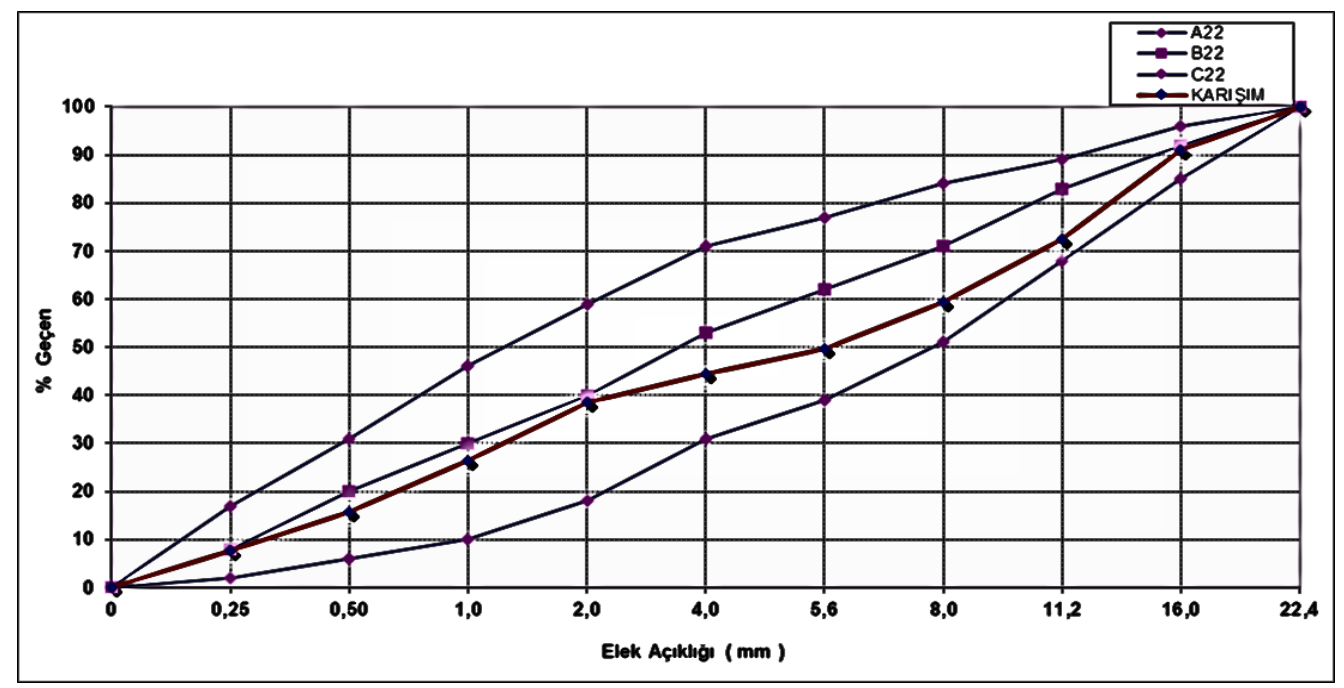

Şekil 11. Beton üretiminde kullanılan agrega karışım oranları Figure 11. Aggregate mixing ratios used in concrete production

Sertleşmiş beton özelliklerini belirlemek amacıyla üretilen taze betondan 10x10x10 cm boyutunda küp kalıplarla numuneler alınmıştır. Numuneler kırılma gününe kadar sıcaklığı $20 \pm 2{ }^{\circ} \mathrm{C}^{\prime}$ olan kirece doygun su ile dolu kür havuzunda bekletilmiştir. TS EN 12390-3 (2019)'e göre 2, 7 ve 28 günlük yaşlar sonrası basınç dayanımı deneyi uygulanmış olup, elde edilen sonuçlar Çizelge $15^{\prime}$ de verilmiştir.

Taze betonun kıvamını ölçmek için TS EN 12350-2 (2019)'e göre üretilen deneme betonların çökme deneyi yapılmıştır. Kireçtaşı agregalarından üretilen deneme betonlarında çökme değeri 170-190 mm arasında ölçülmüştür (Çizelge 15). Çökme deneyi betonun sadece kıvamını ölçmenin yanı sıra betonun işlenebilirliğine dair önemli bilgiler vermektedir. Üretilen deneme betonların birim ağırlıkları ise TS EN 12350-6 (2019)'e göre belirlenmiştir. Kireçtaşı agregalarından üretilen deneme betonlarında birim ağırlık $2306 \mathrm{~kg} / \mathrm{m}^{3}$ ile $2345 \mathrm{~kg} / \mathrm{m}^{3}$ arasında ölçülmüştür (Çizelge 15). Kireçtaşı agregaları ile üretilen betonların beton sınıfı artıkça beton basınç dayanımı artmaktadır (Çizelge 15). Bunun sebebi beton sınıfı artıkça üretilen betonların su/çimento oranının düşük olmasından kaynaklanmaktadır. İncelenen kireçtaşı agrega ile hazırlanan deneme betonlarının 28 günlük basınç dayanımları farklı beton sınıflarında uygun değerlere ulaşmıştır (Çizelge 15). Çimento dozajı arttırıldığında, üretilen deneme betonlarının basınç dayanımlarında C35 betonlarda \%29 artış, C40 betonlarda \%17 artış ve C50 betonlarda ise \%30 artış görülmüştür (Şekil 12). 
Çizelge 14. Üretilen deneme betonların karışım miktarları Table 14. Mixture quantities of the produced trial concretes

\begin{tabular}{|l|c|c|c|c|}
\hline & Deneme-1 & Deneme-2 & Deneme-3 & Deneme-4 \\
\hline Beton Sınıfı & C30/37 & C35/45 & C40/50 & C50/60 \\
\hline Çimento $\left(\mathrm{kg} / \mathrm{m}^{3}\right)$ & 275 & 325 & 345 & 395 \\
\hline Su $\left(\mathrm{kg} / \mathrm{m}^{3}\right)$ & 150 & 164 & 155 & 127 \\
\hline Su/Çimento & 0.55 & 0.50 & 0.45 & 0.32 \\
\hline Doğal Kum $\left(\mathrm{kg} / \mathrm{m}^{3}\right)$ & 310 & 270 & 270 & 240 \\
\hline Kırma Kum $\left(\mathrm{kg} / \mathrm{m}^{3}\right)$ & 550 & 570 & 548 & 539 \\
\hline Kırmataş 1 $\left(\mathrm{kg} / \mathrm{m}^{3}\right)$ & 385 & 382 & 382 & 385 \\
\hline Kırmataş 2 $\left(\mathrm{kg} / \mathrm{m}^{3}\right)$ & 645 & 653 & 656 & 656 \\
\hline Katkı Miktarı $\left(\mathrm{kg} / \mathrm{m}^{3}\right)$ & 2.20 & 2.92 & 4.14 & 5.53 \\
\hline
\end{tabular}

Çizelge 15. Deneme betonların taze beton özellikleri ve basınç dayanımı Table 15. Fresh concrete properties and compressive strength of trial concretes

\begin{tabular}{|c|c|c|c|c|c|}
\hline \multirow{2}{*}{$\begin{array}{c}\text { Karışım } \\
\text { Numarası ve } \\
\text { Beton Sınıfı }\end{array}$} & \multirow{2}{*}{$\begin{array}{l}\text { Birim } \\
\text { Ăğırlık } \\
\left(\mathrm{kg} / \mathrm{m}^{3}\right)\end{array}$} & \multirow{2}{*}{$\begin{array}{c}\text { Çökme } \\
\text { Değeri } \\
(\mathrm{cm})\end{array}$} & \multicolumn{3}{|c|}{$\begin{array}{c}\text { Basınç Dayanımı } \\
\text { (MPa) }\end{array}$} \\
\hline & & & $\begin{array}{c}2 \\
\text { Gün } \\
\end{array}$ & $\begin{array}{c}7 \\
\text { Gün } \\
\end{array}$ & $\begin{array}{c}28 \\
\text { Gün }\end{array}$ \\
\hline $\begin{array}{l}\text { Deneme-1 } \\
\text { C30/37 }\end{array}$ & 2306 & 18 & 21.1 & 32.2 & 39.1 \\
\hline $\begin{array}{c}\text { Deneme-2 } \\
\text { C35/45 }\end{array}$ & 2328 & 18 & 30.1 & 42.1 & 50.5 \\
\hline $\begin{array}{c}\text { Deneme-3 } \\
\text { C40/50 }\end{array}$ & 2337 & 17 & 35.1 & 50.1 & 59.0 \\
\hline $\begin{array}{l}\text { Deneme-4 } \\
\text { C50/60 }\end{array}$ & 2345 & 19 & 53.2 & 66.9 & 76.8 \\
\hline
\end{tabular}

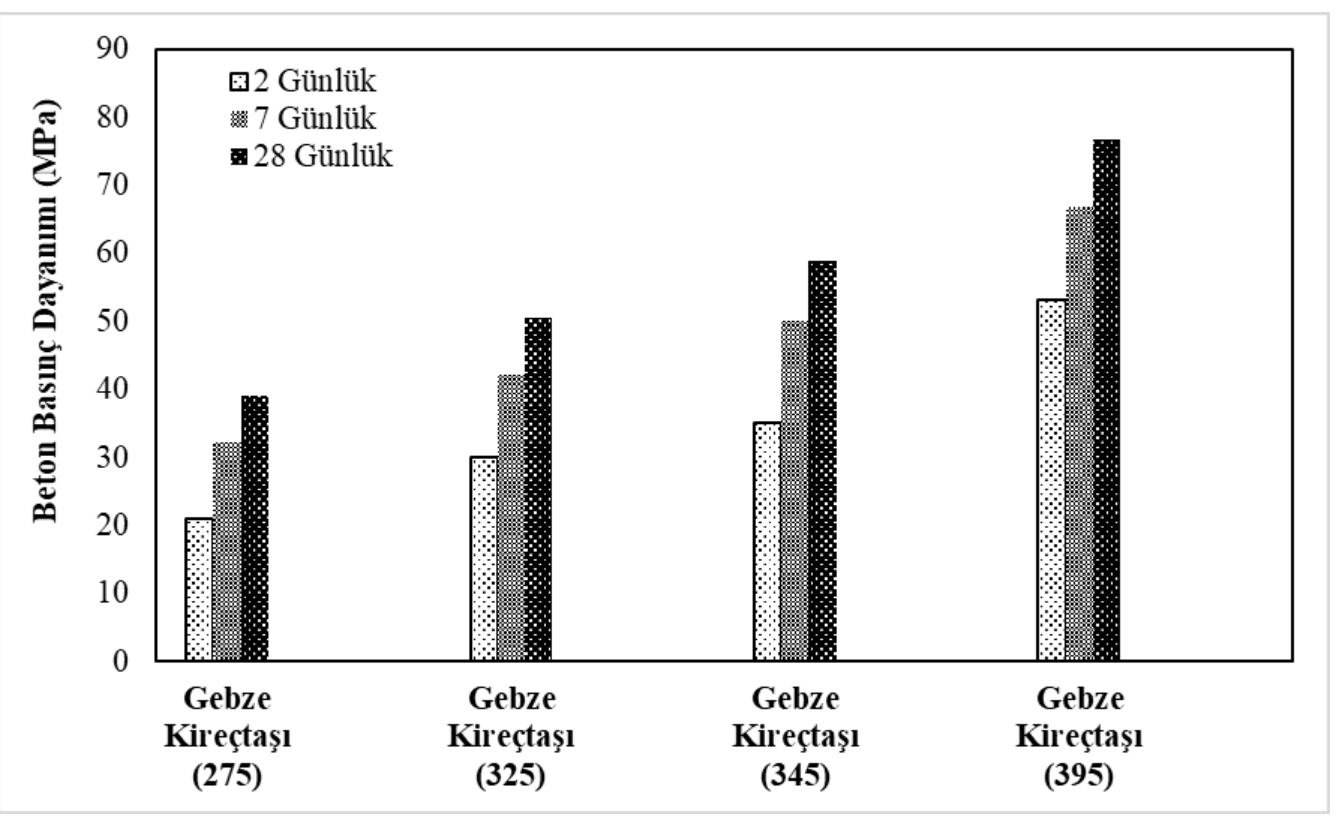

Şekil 12. Kireçtaşı agregalarına ait beton basınç dayanım değerleri Figure 12. Concrete compressive strength values of limestone aggregates 


\section{SONUÇLAR (CONCLUSIONS)}

Kocaeli Gebze Tavşanlı bölgesinde yayılım gösteren Triyas yaşlı kireçtaşlarının beton agregası olarak kullanılabilirlikleri değerlendirilmiştir. Agrega hammaddesi olan kayaçların agrega kalitesini belirlemek için farklı lokasyonlarda örnekleme yapılmıştır. Bu örnekler; petrografik ve mineralojik özelliklerine göre, oomikritik kireçtaşı, yarı mikritik-fosilli kireçtaşı olarak sınıflandırılmıştır. Ayrıca kireçtaşlarının içerdikleri karbonat minerallerinin yüzdelerine göre ise kireçtaşı, saf olmayan kireçtaşı olarak sınıflandırılmıştır. İncelenen kireçtaşlarının ince agregaları, çok ince madde içeriği ( $0,063 \mathrm{~mm}$ geçen) \%3'ü geçtiği için metilen mavisi deneyi yapılmıştır. Metilen mavisi ve su emme değerleri, betonda kullanım açısından uygundur. Kireçtaşlarının boşluk oranının az olması, kil ve silt gibi betonda zararlı ince taneler olan malzemelerin düşük seviyelerde olması, agrega kalitesini artırmaktadır. Agregaların ortalama tane yoğunluğu (özgül ağırlığı), $2.69 \mathrm{Mg} / \mathrm{m}^{3}-2.71 \mathrm{Mg} / \mathrm{m}^{3}$ aralığında olduğu sonucuna ulaşılmıştır. Bu değerler agregaların özgül ağırlıklarının, betonda yaygın olarak kullanılan normal beton değerlerinin içerisinde yer aldığını göstermektedir.

Sülfat, klorür ve toplam kükürt içeriği bakımından incelenen kireçtaşlarının betonda zararlı etkileri bulunmamaktadır. İncelenen kireçtaşlarının iri agregalarının yassılık endeksi standartta göre en uygun alanda bulunmaktadır. Ayrıca iri agregaların Los Angeles parçalanma direnci ve Mikro-Deval aşınmaya karşı direncinin de beton kullanımı için oldukça uygun sonuçlar vermiştir. Kireçtaşları üzerinde yapılan hızlandırılmış harç çubuğu deney sonuçlarının 14 günlük genleşme oranlarının \%0.10'un altında kaldığından alkali silis reaksiyonu yönünden zararsız niteliktedirler. İncelenen kireçtaşı agregalarıyla üretilen deneme betonlardan elde edilen sonuçlara göre, kireçtaşı agregaları normal dayanımlı beton üretimi için uygun özelliktedirler. Günümüzde artan teknoloji ile birlikte betonun kaliteli ve sürekli kullanılması için uygun özellikli agregalar tercih edilmelidir. İncelenen kireçtaşlarının standartlarda belirtilen kabul edilebilir limitler arasında bulunması nedeniyle beton üretiminde beton agregası olarak kullanılmasının uygun olduğu sonucuna ulaşılmıştır.

\section{TEŞEKKÜR (ACKNOWLEDGEMENT)}

Yazarlar bu çalışma kapsamında, sağlanan veriler için İSMAİL DEMİRTAŞ Beton A.Ş.'ye ve laboratuvar çalışmaları sırasında vermiş oldukları katkılardan dolayı İSMAİL DEMİRTAŞ Beton A.Ş.'nin çalışanlarına, özellikle bilgi ve deneyimlerini aktaran Sn. Hakkı YILDIRIM ve Koray TUĞ'a ve makalenin gelişimine katkı veren hakemlere teşekkür eder.

\section{KAYNAKLAR (REFERENCES)}

Al-Jassar, S., Hawkins, A.B., 1991, "The Carboniferous limestone of the Bristol area: a reviev of the influence of the lithology and chemistry on its use as a geomaterial.", Quarterly Journal of Engineering Geology, 24, pp. 143-158

Arsoy, Z., Ersoy, B., Sert, M., Çiftçi, H., Çelik, M.Y., Evcin, A., Yentürk, F., 2018, “ Afyonkarahisar Organize Sanayi Bölgesi Mermer Atıklarının Beton Agregası Olarak Dayanım Özelliklerinin Belirlenmesi" , Araştırma Makalesi, 1st İnternational Engineering and Technology Symposium, Batman University, Say1:1, 1020-1024, Batman.

ASTM C 1260-14 (2014). Standard Test Method for Potential Alkali Reactivity of Aggregates (Mortar-Bar Method). ASTM International, West Conshohocken, PA.

Çelik, M.Y., Arsoy, Z., Sert, M., Ersoy, M., Şahbaz, A., 2018, “İscehisar (Afyonkarahisar) Andezitinin Beton Agregası Olarak Kullanılabilirliğinin İncelenmesi" , Araştırma Makalesi, 1st İnternational Engineering and Technology Symposium, Batman University, Sayı:1, 948-954, Batman.

Eep, Ş., 1987, “Tavşanlı-Demirci (Gebze-Adapazarı) Köyleri Çevresinin Jeolojisi”, Bitirme Tezi, İTÜ Maden Fakültesi, Jeoloji Mühendisliği Bölümü.

Elçi, H., 2011, “Karaburun Yöresi Doğal Yapı Taşlarının Mühendislik Jeolojisi” , Doktora Tezi, D.E.Ü. Fen Bilimleri Enstitüsü, Jeoloji Mühendisliği Bölümü, 287-302, İzmir. 
Elçi, H., Türk, N., İşintek, İ., 2014, “İzmir Karaburun Yarımadasındaki Farklı Kireçtaşlarının Beton Agregası Olarak Değerlendirilmesi" , Araştırma Makalesi, Jeoloji Mühendisliği Dergisi, Sayı:38, 118-127, Ankara.

Erdoğan, T.Y., 2003, Beton, ODTÜ Geliştirme Vakfı Yayıncılık ve İletişim A.Ş. Yayını, Ankara.

Eren, H., Nasuf, E., Ökten, G., Energen, T., 1996, “Kocaeli-Gebze İlçesi, Tavşanlı Köyü Civarındaki Kireçtaşı Sahalarının Jeolojisi, Rezerv Analizi ve İstanbul Metropolü Yönünden Önemi", 1. Ulusal Kırmataş Sempozyomu, 53-68, İstanbul.

Folk, R. L., 1962, Spectral Subdivision of Limestone Types. In: W.E. Ham (ed.), Classification of Carbonate Rocks, American Association Petroleum Geologist, 1, 62-84.

Fookes, P.G., 1980, "An Introduction to the Influence of Natural Aggregates on the Performance and Durability of Concrete", Quarterly Journal of Engineering Geology, 123, 207-229.

Gutierrez, P., and Canovas, M.F., 1996, "High Performance Concrete Requirements for Constituent Materials and Mix Proportioning", ACI Materials Journal, 93, 233-241.

Güler, B., Tuğrul, A., Hasdemir, S., Şahin, S.Y., 2010, “İstanbul'da Üretilen Farklı Kökenli Agregaların Beton Özelliklerine Etkileri", Mühendislik Jeolojisi Bülteni, Sayı:30, 53-72, Ankara.

Gürsel, E., Erenson, C., 2017, “Kayaç Türünün Betonun Yüksek Dayanımına Etkisinin Petrografik Olarak İncelenmesi", Ulusal Mühendislik Jeolojisi-Jeoteknik Sempozyumu, Adana.

Halili, A., Gözübol A.M., 1999, “Hereke Formasyonunun (Gebze Kireçtaşı) Kırmataş Özelliği ve Kırma Eleme Tesislerindeki Davranışı", 2. Ulusal Kırmataş Sempozyumu, 89-98, İstanbul.

Hasdemir, S., 2007, "Marmara Bölgesindeki Farklı Kökenli Doğal Kumların Beton Özelliklerine Etkisi”, Doktora Tezi, İstanbul Üniversitesi, Fen Bilimleri Enstitüsü, İstanbul.

Keskin, G., 2011, “Cendere Vadisi Kayaçlarının Beton Agregası Olarak Değerlendirilmesi”, Yüksek Lisans Tezi, İstanbul Teknik Üniversitesi, Fen Bilimleri Enstitüsü, İstanbul.

Poitevin, P., 1999, "Limestone Aggregate Concrete, Usefulness and Durability", Cement and Concrete Composites, 21, 89-97.

Sayar, C., 1976, "Haliç ve Civarının Jeolojisi” B.Ü. İstanbul Haliç Sorunları ve Çözüm Yolları Ulusal Sempozyumu Bildiriler Kitabı, 355-374, İstanbul.

Taşdemir, C., 1998, "The Influence of Aggregate Type on the Mechanical Properties of Concrete", Proceedings of the 12th European Ready Mixed Concrete Congress, Lisbon, pp. 633-640.

Tosun, K., Yazıcı, H., Yiğiter, H., Baradan, B., 2003, “Uçucu Kül İçeren Çimento Harçlarının Sülfat Dayanıklılı̆̆ının İncelenmesi", 5. Ulusal Beton Kongresi, 17-26, İstanbul.

TS EN 197-1, 2012, Genel Çimentolar - Bileşim, Özellikler ve Uygunluk Kriterleri, Türk Standartları Enstitüsü, Ankara.

TS EN 933-1, 2012, Agregaların Geometrik Özellikleri İçin Deneyler - Bölüm 1: Tane Büyüklüğü Dağılımı Tayini - Eleme Yöntemi, Türk Standartları Enstitüsü, Ankara.

TS EN 933-3, 2012, Agregaların Geometrik Özellikleri İçin Deneyler - Bölüm 3: Tane Şekli Tayini - Yassılık Endeksi, Türk Standartları Enstitüsü, Ankara.

TS EN 933-9+A1, 2014, Agregaların Geometrik Özellikleri İçin Deneyler - Bölüm 9: İnce Tanelerin Tayini - Metilen Mavisi Deneyi, Türk Standartları Enstitüsü, Ankara.

TS EN 1097-1, 2011, Agregaların Mekanik ve Fiziksel Özellikleri İçin Deneyler - Bölüm 1: Aşınmaya Karşı Direncin Tayini (Mikro-Deval), Türk Standartları Enstitüsü, Ankara.

TS EN 1097-2, 2010, Agregaların Mekanik ve Fiziksel Özellikleri İçin Deneyler - Bölüm 2: Parçalanma Direncinin Tayini İçin Yöntemler, Türk Standartları Enstitüsü, Ankara.

TS EN 1097-6, 2013, Agregaların Mekanik ve Fiziksel Özellikleri İçin Deneyler - Bölüm 6: Tane Yoğunluğunun ve Su Emme Oranının Tayini, Türk Standartları Enstitüsü, Ankara.

TS EN 1744-1+A1, 2013, Agregaların Kimyasal Özellikleri İçin Deneyler - Bölüm 1: Kimyasal Analiz, Türk Standartları Enstitüsü, Ankara.

TS EN 12350-2, 2019, Taze Betonda Çökme (Slump) Deneyi, Türk Standartları Enstitüsü, Ankara. TS EN 12350-6, 2019, Taze Betonda Yoğunluk Tayini, Türk Standartları Enstitüsü, Ankara.

TS EN 12390-3, 2019, Deney Numunelerinin Basınç Dayanımı Tayini, Türk Standartları Enstitüsü, Ankara. 
TS 706 EN 12620, 2003, Beton Agregaları, Türk Standartları Enstitüsü, Ankara.

Tuğrul, A., Yılmaz, M., Ündül, Ö., Kara, G., ve Buldum, M., 2008, “İstanbul'un Anadolu Yakasındaki Kumtaşlarının Beton Üretiminde Kullanılabilirlikleri", Beton 2008 Kongre Bildirileri, 130-144, İstanbul.

Uribe-Afif, R., 1994, Study of petrous aggregates for concrete in Zimapan arch dam in Mexico, Proceedings of 7th International IAEG Congress, pp. 3229-3233.

Williams, D.M., and McNamara, K., 1992, "Limestone to dolomite to dedolomite conversion and its effect on rock strength: a case study.", Quarterly Journal of Engineering Geology, 24, pp. 131-135.

Yılmaz, F., Koltka, S., Sabah, E., 2011, “Emirdağ-Adaçal (Afyonkarahisar) Kireçtaşlarının Beton Agregaları Standardına Uygunluğunun Araştırılması", Araştırma Makalesi, Afyon Kocatepe Üniversitesi Fen Bilimleri Dergisi, Sayı:11, 1-12, Afyonkarahisar.

Zarif, İ.H., Tuğrul, A., ve Dursun, G., 2003, “İstanbul'daki Kireçtaşlarının Agrega Kalitesi Yönünden Değerlendirilmesi", İstanbul Üniversitesi Mühendislik Fakültesi Yerbilimleri Dergisi, 16, 61-70. 